\title{
Obesity and diabetes cause cognitive dysfunction in the absence of accelerated $\beta$-amyloid deposition in a novel murine model of mixed or vascular dementia
}

\author{
Dana M Niedowicz ${ }^{1}$, Valerie L Reeves ${ }^{1,2}$, Thomas L Platt ${ }^{2}$, Katharina Kohler ${ }^{1}$, Tina L Beckett ${ }^{1}$, David K Powell ${ }^{4}$, \\ Tiffany L Lee ${ }^{1,3}$, Travis R Sexton ${ }^{2}$, Eun Suk Song ${ }^{2}$, Lawrence D Brewer ${ }^{3}$, Caitlin S Latimer ${ }^{3}$, Susan D Kraner ', \\ Kara L Larson², Sabire Ozcan², Christopher M Norris ${ }^{1,3}$, Louis B Hersh², Nada M Porter ${ }^{3}$, Donna M Wilcock ${ }^{1,3}$ \\ and Michael Paul Murphy, ${ }^{1, *}$
}

\begin{abstract}
Mid-life obesity and type 2 diabetes mellitus (T2DM) confer a modest, increased risk for Alzheimer's disease (AD), though the underlying mechanisms are unknown. We have created a novel mouse model that recapitulates features of T2DM and AD by crossing morbidly obese and diabetic $d b / d b$ mice with APP ${ }^{\text {NNL } \triangle N L} \times$ PS $P^{\text {P264LPP264L }}$ knock-in mice. These mice ( $d b / A D)$ retain many features of the parental lines (e.g. extreme obesity, diabetes, and parenchymal deposition of $\beta$-amyloid $(A \beta)$ ). The combination of the two diseases led to additional pathologies-perhaps most striking of which was the presence of severe cerebrovascular pathology, including aneurysms and small strokes. Cortical $A \beta$ deposition was not significantly increased in the diabetic mice, though overall expression of presenilin was elevated. Surprisingly, $A \beta$ was not deposited in the vasculature or removed to the plasma, and there was no stimulation of activity or expression of major A $\beta$-clearing enzymes (neprilysin, insulin degrading enzyme, or endothelin-converting enzyme). The $d b / A D$ mice displayed marked cognitive impairment in the Morris Water Maze, compared to either $d b / d b$ or APP ${ }^{A N L} \times P S 1^{P 264 L}$ mice. We conclude that the diabetes and/or obesity in these mice leads to a destabilization of the vasculature, leading to strokes and that this, in turn, leads to a profound cognitive impairment and that this is unlikely to be directly dependent on A $\beta$ deposition. This model of mixed or vascular dementia provides an exciting new avenue of research into the mechanisms underlying the obesity-related risk for age-related dementia, and will provide a useful tool for the future development of therapeutics.
\end{abstract}

Keywords: Dementia, Diabetes, Obesity, Stroke, Alzheimer's disease

\section{Introduction}

Alzheimer's disease (AD) is a neurodegenerative disease affecting the elderly. There are two major neuropathologies associated with $\mathrm{AD}$ : extracellular plaques containing $\beta$-amyloid $(A \beta)$ and intracellular neurofibrillary tangles composed of the microtubule-associated protein tau. The combined insults of $A \beta$ and tau accumulation are thought

\footnotetext{
*Correspondence: mpmurp3@email.uky.edu

'Sanders Brown Center on Aging, University of Kentucky, 800 S. Limestone, Sanders Brown 211, Lexington, KY 40536-0230, USA

2Department of Molecular and Cellular Biochemistry, University of Kentucky, Lexington, USA

Full list of author information is available at the end of the article
}

to promote the progressive synaptic failure and neuronal loss, leading to memory loss and cognitive impairment [1-4]. While familial forms of AD exist, sporadic AD is far more common. Though the two forms of AD ultimately reflect similar pathologies, the underlying causes vary. Familial AD is linked to specific mutations in amyloid precursor protein (APP) or presenilin (PS1 or PS2), leading to accumulation of toxic $\beta$-amyloid species in the brain by mid-life. Sporadic AD manifests later in life, and the triggers are less clear and likely complex. Though there are genetic components associated with sporadic $\mathrm{AD}$, environmental factors, such as lifestyle (e.g. diet and 
exercise), are also likely to impact disease onset and progression.

Obesity is a major worldwide public health problem, and is associated with the metabolic disorder type 2 diabetes mellitus (T2DM). Diabetes is associated with cognitive decline in both rodents and humans [5-7]. Due to improved treatments, T2DM patients are living longer, putting them at increased risk for age-related complications. Although simply living to an older age increases the risk of Alzheimer's disease, there is a well-known (albeit poorly understood) link between obesity, T2DM and dementia [8]. The form of dementia afflicting these individuals combines elements of vascular pathology, small strokes and AD-related neuropathology. In fact, the amount of AD pathology is essentially unchanged in cases with a history of T2DM, while cerebrovascular pathology increases $[9,10]$. Vascular dementia, or even cerebrovascular dysfunction as a general AD comorbidity, is a poorly understood condition with no viable treatment options. This is due to cerebrovascular dysfunction being understudied as a major cause of dementia and the lack of useful model systems in which to develop therapies or to study the disease process.

In this paper, we describe the creation of a novel mouse model combining the key features of obesity, diabetes, and AD. We crossed the obese and diabetic $d b / d b$ mouse [11-13] with the $\mathrm{APP}^{\Delta \mathrm{NL} / \Delta \mathrm{NL}} \times \mathrm{PS}^{\mathrm{P} 264 \mathrm{~L} / \mathrm{P} 264 \mathrm{~L}}$ knock-in model of $\mathrm{AD}[14,15]$. The resulting mice (which we have called $d b / A D$ ) are morbidly obese, glucose intolerant, insulin resistant, and display parenchymal amyloid plaques, similar to the parental lines. In addition, although these mice had profound cognitive impairment and marked cerebrovascular abnormalities, this does not appear to be driven by $\mathrm{A} \beta$ deposition. The $\mathrm{db} / \mathrm{AD}$ mice will be a useful tool with which to study the intersection of T2DM and dementia.

\section{Materials and methods \\ Mouse breeding}

In order to create a diabetic AD mouse model, we crossed the obese, diabetic $L e p r^{d b / d b}(d b / d b)$ mice [11-13] with the $A P P^{\triangle N L / \triangle N L} / P S 1^{P 264 L / P 264 L}$ (APP/PS1) knock-in model of $\mathrm{AD}[14,15]$. Because the homozygous $d b / d b$ mice are infertile, heterozygous $\left(\mathrm{Lepr}^{\mathrm{db} /{ }^{+}}\right)$mice on a C57Bl/6 J background (Jackson Labs; Bar Harbor, ME) were bred with APP/PS1 mice on a CD-1/129 background (obtained from the breeding colony at the University of Kentucky). The resulting F1 mice heterozygous for all three alleles were then intercrossed to generate wild-type, heterozygous, and homozygous $d b$ mice that were either wild-type or homozygous for the AD knock-in genes. For most of the data presented here, we focused on four main genotypes: wild-type (WT; Lepr $\left.^{+/+} \times A P P^{+/+} / P S 1^{+/+}\right), \mathrm{db}\left(\operatorname{Lepr}^{d b / d b} \times\right.$ $\left.\mathrm{APP}^{+/+} / \mathrm{PS1}^{+/+}\right)$, AD $\left(\mathrm{Lepr}^{+/+} \times A P P^{\Delta N L / \Delta N L} / P S 1^{\mathrm{P} 264 L /}\right.$ $\left.{ }^{P 264 L}\right)$, and $\mathrm{db} / \mathrm{AD}\left(\right.$ Lepr $^{d b / d b} \times A P P^{\Delta N L / \Delta N L} / P S 1^{P 264 L /}$ $\left.{ }^{P 264 L}\right)$. Some analyses included $\mathrm{Lepr}^{\mathrm{db} /+} A P P^{+/+} / \mathrm{PS1}^{+/+}$ and $\mathrm{Lepr}^{\mathrm{db} /+} \times A P P^{\Delta N L / \Delta N L} / P S 1^{P 264 L / P 264 L}$ mice (noted where appropriate). Mice were housed under a 12 hour light-dark cycle and fed standard rodent chow ad libitum. Mice were euthanized by $\mathrm{CO}_{2}$ asphyxiation, followed by decapitation. All animal work was conducted with prior University of Kentucky (UK) IACUC approval, and was performed in accordance with USDA and PHS guidelines.

\section{Genotyping}

Tail snips were collected prior to weaning. For some of the $d b$ and $A P P$ genotyping, tail snips were sent to Transnetyx (Cordova, TN) for purification and analysis. For those analyzed in our lab, as well as PS1 genotyping, genomic DNA was isolated and purified from tail snips using the Promega Wizard Genomic DNA kit (Promega; Madison, WI). $d b$ genotyping was performed using a single nucleotide polymorphism Taqman ${ }^{\circledast}$ genotyping kit (Applied Biosystems Life Technologies; Grand Island, NY). APP and PS1 genotyping were performed by PCR as described previously [16] using GoTaq ${ }^{\circ}$ Flexi DNA Polymerase (Promega).

\section{Mouse groups}

The mice used for this study were broadly divided by age and will be referred to as young (1-4 months old: $3.0 \pm 0.8$ months), middle-aged (5-9 months old: $7.2 \pm$ 1.6 months), and older (10-14 months old: $12.2 \pm$ 1.0 months) based on the predicted lifespan of the $d b / A D$ mice ( 15-16 months).

\section{Glucose and insulin tolerance tests}

Mice were fasted 3-6 hours prior to the start of the glucose tolerance test (GTT) or insulin tolerance test (ITT). All glucose measurements were obtained via tail bleed using a Bayer Breeze 2 glucometer and test strips (Bayer; Tarrytown, NY). For the GTT, a baseline measurement was obtained after which the GTT was initiated by intraperitoneal injection of dextrose $(2 \mathrm{mg} / \mathrm{g}$ : Hospira; Lake Forrest, IL). Subsequent measurements were recorded at $15,30,60$, and 120 minutes post-injection. For the ITT, a baseline glucose measurement was taken, after which insulin $(0.75 \mathrm{U} / / \mathrm{kg}$ : Eli Lilly; Indianapolis, IN) was injected intraperitoneally. Subsequent measurements were recorded at 15, 30, 60, and 120 minutes post-injection. Any glucometer reading of "HI" was set to $700 \mathrm{mg} / \mathrm{dL}$ for data analysis.

\section{Blood pressure measurements}

Blood pressure (BP) was measured using a Kent CODA 8 BP machine (Kent Scientific; Torrington, CT). Animals were allowed to acclimate to the tail blood pressure cuff for five minutes on a warming platform before recording 
BP measures. The BP measures consisted of 20 cycles of diastolic/systolic measures, with a 20 second rest period between cycles. After finishing the data collection, the mice were immediately released back into their home cages. The rodent restraints, cuffs, and warming platform were cleaned between animals; female animals were always run after male animals to avoid any possible irritation of the males. BP measures were performed at the same time each day to account for the possible influence of circadian rhythms.

\section{Plasma measurements}

Blood was collected upon decapitation in the presence of EDTA, centrifuged $(1500 \times g, 10 \mathrm{~min}$.), and the plasma collected. Plasma leptin was measured by a commerciallyavailable, species-specific ELISA (EMD Millipore; Billerica, $\mathrm{MA})$, according to package instructions.

\section{Immunoassays}

Frozen brain tissue was serially extracted in either PBS or HEPES (20 mM HEPES, 2 mM EDTA, 2 mM EGTA, $0.32 \mathrm{M}$ sucrose) followed by $2 \%$ SDS, and $70 \%$ formic acid as previously described $[17,18]$. Buffers were supplemented with protease inhibitor cocktail (Amresco; Solon, $\mathrm{OH}$ ) and phosphatase inhibitor cocktail (EMD Millipore). The tissue was homogenized using an AHS200 PowerMax (VWR; Radnor, PA) homogenizer, the insoluble material was removed by centrifugation (PBS/HEPES/ SDS: $20,800 \times g, 30$ minutes; formic acid; $20,800 \times g$, $60 \mathrm{~min})$ and the supernatants frozen until use. Humanspecific $A \beta$ was measured by two-site sandwich ELISA as previously described [17]. Oligomeric A $\beta$ (mouse and human) was measured by single-site sandwich ELISA as previously described $[19,20]$. Briefly, 384-well plates (Immulon 4HBX: Thermo Scientific; Waltham, MA) were coated with either $0.5 \mu \mathrm{g} A b 42.5\left(\mathrm{~A} \beta_{\text {total }}\right.$ and $\left.\mathrm{A} \beta_{1-40}\right)$, Ab2.1.3 (A $\left.\beta_{1-42}\right)$, or 4G8 (oligomers: Covance, Princeton, NJ)/well and blocked with Synblock (Serotec; Raleigh, NC) for two hours. PBS and SDS extracts were diluted in AC buffer (0.2 M sodium phosphate ( $\mathrm{pH} 7), 0.4 \mathrm{M}$ $\mathrm{NaCl}, 2 \mathrm{mM}$ EDTA, 0.4\% Block Ace (Serotec), 0.4\% BSA, $0.05 \%$ CHAPS, $0.05 \% \mathrm{NaN}_{3}$ ) for analysis. Formic acid extracts were first neutralized with TP buffer $(1 \mathrm{M}$ Tris base, 0.5 M sodium phosphate: 20-fold dilution), then further diluted with AC buffer for analysis. Similarly, plasma was diluted in AC buffer for analysis. A standard curve was prepared from recombinant human $\mathrm{A} \beta_{1-42}, \mathrm{~A} \beta_{1-40}$, or oligomeric $\mathrm{A} \beta$ diluted in $\mathrm{AC}$ buffer. Standards and samples were measured at least in duplicate. After incubation with the samples and standards, $A \beta$ was detected with either biotinylated-4G8 (A $\beta_{\text {total }}$, $\mathrm{A} \beta_{1-42}$, and oligomers: Covance) or biotinylated-13.1.1 $\left(A \beta_{1-40}\right)$, followed by incubation with $0.1 \mu \mathrm{g} / \mathrm{mL}$ NeutrAvidin-HRP (Pierce Technologies; Rockford, IL).
The plate was developed with $3^{\prime}, 3^{\prime}, 5^{\prime}, 5^{\prime}$-tetramethylbenzidine (Kirkeguard and Perry Laboratories; Gaithersburg, $\mathrm{MD}$ ) and the reaction stopped with 6\% o-phosphoric acid. The absorbance at $450 \mathrm{~nm}$ was measured with a BioTek (Winooski, VT) multiwell plate reader.

Protein levels of PS1, BACE1, BACE2, phosphorylated and total tau, endothelin-converting enzyme 1 (ECE1), and PSD95 were determined by Western or spot blot, using protein-specific antibodies (PS1 (EMD Millipore), BACE1 (Epitomics; Burlingame, CA), BACE2 (Abcam; Cambridge, MA), pTau (AT8: Sigma-Aldrich; St. Louis, MO), total tau (HT7: Pierce: [21,22]), ECE1 (Acris Antibodies; San Diego, CA), PSD95 (D27E11; Cell Signaling; Danvers, MA)). Immunoreactive bands for PS1, BACE1, BACE2, tau, and ECE1 were visualized with Super Signal West Dura chemiluminescence HRP substrate (Pierce) after incubation with HRP-conjugated secondary antibodies and exposed to film. Densitometric analyses were performed using Image J software. Expression was standardized to $\beta$-actin (Sigma-Aldrich) or GAPDH (Abcam) expression in the same lane or spot, respectively. PSD95 and its GAPDH loading control (Abcam) were visualized with fluorescently-labeled secondary antibodies (LI-COR; Lincoln, NE) using an Odyssey Infrared Imager (LI-COR) for quantitation and analysis.

\section{qPCR}

Tissue was homogenized in Trizol ${ }^{\mathrm{Tm}}$ (Invitrogen; Grand Island, NY) in order to isolate RNA, followed by phenol/ chloroform extraction. When needed, RNA was further purified by RNeasy columns (Qiagen; Valencia, CA). Expression of ECE1 and ECE2 were determined by two-step qRT-PCR, using iScript (BioRad; Hercules, CA) reverse transcription, followed by qPCR with PerfeCTa FastMix ${ }^{\text {TM }}$ (Quanta BioSciences; Gaithersburg, MD). The geometric mean of the $C_{T}$ values for RPL30, cyclophilin, and RNA polymerase IIJ was used as an internal control to calculate and compare relative expression $\left(2_{\mathrm{T}}^{-\Delta \Delta C}\right)$. Gene specific primer sets were obtained from IDT (Coralville, IA).

\section{Neprilysin and insulin degrading enzyme activity}

Neprilysin (NEP) activity was measured as described [23]. Briefly, hemibrains were homogenized in ice-cold Tris buffer (50 mM Tris- $\mathrm{HCl}$ and $150 \mathrm{mM} \mathrm{NaCl}, \mathrm{pH} 7.2$; $100 \mathrm{mg} / \mathrm{mL}$ ) supplemented with $1 \mathrm{mM}$ PMSF (SigmaAldrich), and $10 \mu \mathrm{M}$ E-64 (RPI; Mt. Prospect, IL). The homogenate was centrifuged $\left(1000 \times g, 20 \mathrm{~min} ., 4^{\circ} \mathrm{C}\right)$, followed by a high-speed centrifugation of the supernatant $\left(100,000 \times g, 1\right.$ hour, $\left.4^{\circ} \mathrm{C}\right)$. The supernatant was removed, and the pellet resuspended in Tris buffer for the enzyme assay. NEP activity was measured using glutaryl-AlaAla-Phe-4-methoxy-2-naphthylamide (Sigma-Aldrich) as a substrate. Reactions were initiated with the addition of the membrane fraction, then fluorescent product formation 
was monitored (340 $\mathrm{nm}$ excitation, $425 \mathrm{~nm}$ emission, $\left.37^{\circ} \mathrm{C}\right)$. Phosphoramidon $(50 \mu \mathrm{M})$ and thiorphan $(10 \mu \mathrm{M})$ were used to inhibit NEP activity and determine background fluorescence for each sample.

Insulin degrading enzyme (IDE) activity was measured using a commercially-available kit (EMD Millipore) according to manufacturer's instructions. Briefly, hemibrains were homogenized in Tris buffer $(100 \mathrm{mg} / \mathrm{mL})$ supplemented with PMSF and E-64, centrifuged $(20,800 \times g$, $30 \mathrm{~min} .4^{\circ} \mathrm{C}$ ), and the supernatant used for the activity assay. Samples were compared against rat IDE. Fluorescence was measured at an excitation wavelength of $320 \mathrm{~nm}$ and an emission wavelength of $405 \mathrm{~nm}$.

\section{MRI}

T2\%-MRI was performed using a horizontal bore Bruker Clinscan (7.0 T, 30 cm, 300 MHz: Billerica, MA) imager equipped with a triple-axis gradient $(630 \mathrm{mT} / \mathrm{m}$ and $6300 \mathrm{~T} / \mathrm{m} / \mathrm{s}$ ) and a helium-cooled $14 \mathrm{~K}$ quadrature head cryo-coil, cooled to $20^{\circ} \mathrm{K}$. T2*-weighted images were acquired with a 2D GRE sequence with at $34 \mu \mathrm{m} \times 34 \mu \mathrm{m} \times$ $400 \mu \mathrm{m}$ resolution, $15 \mathrm{~mm}$ FOV, 25 degree flip angle, 10 averages, TR $165 \mathrm{~ms}$, and TE $15.3 \mathrm{~ms}$. Mice were imaged under constant isofluorane anesthesia and their body temperature and respiration were continuously monitored. At least ten equally-spaced images were taken of each mouse brain. Asymmetrically-occurring dark spots on the images were considered indicative of vascular events (confirmed histologically, see below), whereas symmetrically-occurring dark areas were considered to be blood vessels and were excluded.

\section{Vascular corrosion casting}

Vascular corrosion casting was performed as described [24]. Briefly, mice were anesthetized using pentobarbital (100 $\mathrm{mg} / \mathrm{kg}$ ), followed by transcardial perfusion with heparinized saline $(0.9 \%)$. Following a brief perfusion with para-formaldehyde (4\%), the brains were perfused with the polyurethane resin Pu4ii (4 mL/min: VasQtec; Switzerland). After allowing the resin to cure for at least two days, the brains were incubated in $\mathrm{KOH}\left(7.5 \%, 50^{\circ} \mathrm{C}\right.$, $48 \mathrm{~h})$, followed by formic acid $\left(5 \%, 50^{\circ} \mathrm{C}, 24 \mathrm{~h}\right)$. The tissue was subsequently frozen, then lyophilized to macerate the soft tissue. Finally, the casted brains were sputter-coated in palladium and viewed by scanning electron microscopy (Hitachi S-4300: Schaumburg, IL), using the middle cerebral artery as a landmark. Endothelial cell density was determined by endothelial cell nuclear imprints measured directly using Image J software. Aneurysm pathology was assessed on a 4 point scale based on clear data break points $(0=$ none; $1=1$ possible; $2=1-3$ definite; $3=4+$ definite. Vascular density was determined by rank order of representative images using three blinded, independent reviewers. Images were scored from 1 (most dense) - 26 (least dense), and the ranks from the three reviewers averaged.

\section{Histology}

Tissue was harvested and fixed in PBS-buffered 10\% formalin for at least 24 hrs. For A $\beta$ immunohistochemistry, hemibrains were embedded in a matrix and sectioned $(30 \mu \mathrm{m})$ by NeuroScience Associates (Knoxville, TN). For Prussian blue staining, hemibrains were embedded in paraffin and sectioned to $8 \mu \mathrm{m}$ using a microtome. For free-floating sections, the hemibrains were incubated in sucrose $(10 \%, 20 \%, 30 \%$ sequentially for 24 hours each) for cryoprotection, then sectioned on a sliding, freezing microtome to $25 \mu \mathrm{m}$.

Perl's Prussian blue staining of hemosiderin was performed as described [25]. Immunohistochemistry detecting $A \beta$ was performed using antibody 4G8 (Covance) as described [19]. Some A $\beta$ immunohistochemistry was performed by NeuroScience Associates. Densitometry was performed on these sections using Image J software. Vascular $\mathrm{A} \beta$ was visualized by three different methods: 1) Congo red ( $0.2 \%$ in $\mathrm{NaCl}$-saturated $80 \%$ ethanol), 2 ) Thioflavin S (1\%: Sigma-Aldrich), and 3) resorufin (Sigma-Aldrich: [26]). Cerebral blood vessels were imaged in free-floating sections using a mouse anti- $\alpha$-actin antibody (A5228: Sigma-Aldrich), followed by quantitation with Image J software. Triple labeling of free-floating sections was performed with the fluorescent $A \beta$-specific Amylo-Glo stain (Biosensis; Thebarton, Australia), rabbit anti-collagen IV (ab6586: Abcam), and rabbit anti-glial fibrillary acidic protein (G9269: Sigma-Aldrich).

\section{Behavioral testing}

Testing was performed by the UK Rodent Behavioral Core (http://www.rodentbehaviorcore.uky.edu/default.aspx/0_UK_ Rodent_Behavior_Core). Mice were tested using the Morris Water Maze paradigm. The maze consisted of a circular pool (134.5 cm diameter) filled with $25^{\circ} \mathrm{C}$ water. A circular platform (11 cm diameter) was placed in the northeast quadrant $1 \mathrm{~cm}$ below the surface of the water so that it was not visible. Nontoxic tempura paint was used to create opaque water, thus obscuring the platform. The pool was placed behind dark curtains holding external maze cues. The cues were rotated each day. There were five consecutive training/acquisition days. On each-training day the animals swam four trials (rotating initial placement each time), lasting one minute each, with a five minute interval between trials. After a 30 minute rest upon the conclusion of training on the fifth day, we performed a probe trial where the platform was removed from the pool. The animal's location in the pool was recorded for one minute and used to calculate the time spent in the target quadrant and the number of times crossing the platform area. After the completion of training, mice were 
tested for visual acuity during which the external cues were provided along with a visibly-raised platform. The mice were tested for visual acuity in four trials during one day. Water Maze data (e.g. swim speed, distance, latency to platform. etc.) were collected and analyzed using EthoVision XT software (Noldus Information Technology; Leesburg, VA).

\section{Passive immunization}

A small number of $\mathrm{db} / \mathrm{AD}$ mice $(\mathrm{N}=7$; 9-12 month old; $3 \mathrm{M} / 4 \mathrm{~F})$ were injected intraperitoneally with Ab42.5 (300 $\mu \mathrm{g}$ in sterile saline) every two weeks for two months. Mice were imaged by T2* MRI prior to starting the treatment (baseline) and prior to death (endpoint). The majority of the brains $(\mathrm{N}=6 ; 2 \mathrm{M} / 4 \mathrm{~F})$ were extracted in RIPA buffer $(50 \mathrm{mM}$ Tris- $\mathrm{HCl}, 150 \mathrm{mM}$ $\mathrm{NaCl}, 1 \%$ Triton $\mathrm{X}-100,0.5 \%$ deoxycholate, 0.1\% SDS; $\mathrm{pH}=8.0$ ) with protease inhibitor cocktail (Amresco) for $\mathrm{A} \beta_{\text {total }}$ ELISA measurement as described above. Brains from untreated, age-matched $\mathrm{db} / \mathrm{AD}$ mice $(\mathrm{N}=6 ; 2 \mathrm{M}$ / 4 F) were also extracted in RIPA and used as controls. Endpoint MRI scans were compared against untreated, age-matched (11-14 months old) db/AD mice.

\section{Statistics}

Weight data were analyzed by student's t-test at each age using Microsoft Excel, and the probability adjusted using the Holm-Bonferroni method [27]. All other data were analyzed with SPSS (Hewlett Packard; Palo Alto, CA) using the general linear model (GLM) module for ANOVA with the independent variables gender, $\mathrm{db}$ genotype, and $\mathrm{AD}$ genotype (for an explanation of this model, see http://pic.dhe.ibm.com/infocenter/spssstat/

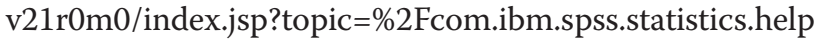
\%2Fidh_glm_multivariate.htm). Post-hoc multiple comparisons were conducted using Tukey's test, Dunnett's test, or similar. Chi-square analyses were performed on the visual acuity measurements for the Morris Water Maze. We performed correlation analyses using either Pearson's $r$ or Spearman's $\rho$ (parametric and nonparametric values, respectively), and adjusted probability using the Holm-Bonferroni method. For nonparametric comparisons, we used a Kruskal-Wallis ANOVA, or MannWhitney U test, where appropriate. For most presented statistics, we note an overall effect of genotype ( $d b$ or $A D)$ across the data set. In some cases, we also present a direct comparison between two different genotypes.

\section{Results}

Creation and characterization of the $\mathrm{db} / \mathrm{AD}$ mouse model In order to explore the mechanisms underlying the increased risk for $\mathrm{AD}$ in T2DM patients, we created a unique mouse model that recapitulates features of both diseases. The obese, leptin-resistant, and diabetic $d b / d b$
$\left(L e p r^{d b / d b}\right)$ mouse was crossed with the $A P P^{\Delta N L / \Delta N L} x$ $P S 1^{P 264 L / P 264 L}$ knock-in model of AD. Since APP and PS1 are under the control of their endogenous promoters, expression follows normal murine levels and patterns. The resulting mice homozygous for the $L e p r^{d b}$ mutation were morbidly obese (Figure 1a). In addition, young $L e p r^{d b / d b}$ mice displayed elevated fasting glucose and impaired glucose tolerance (Figure 1b: F[2, 30] = 38.2, $\mathrm{p}<0.0001)$. On average, Lepr ${ }^{d b / d b}$ mice were 2-fold heavier than Lepr $^{+/+}$and Lepr ${ }^{d b /+}$ mice (Figure 1c-d: $\mathrm{p} \leq$ 0.001 for all ages). The AD genotype had no effect on weight ( $\mathrm{p} \geq 0.3$ for all ages). Consistent with their increased weight, older Lepr ${ }^{d b / d b}$ mice had significantly more plasma leptin $(168 \pm 15 \mathrm{ng} / \mathrm{mL} ; \mathrm{n}=9 \mathrm{~F} / 17 \mathrm{M})$ than Lepr $^{+/+}(54 \pm 15 \mathrm{ng} / \mathrm{mL} ; \mathrm{n}=6 \mathrm{~F} / 20 \mathrm{M})$ or Lepr $^{\mathrm{db} /+}(49 \pm$ 15; $\mathrm{n}=11 \mathrm{~F} / 15 \mathrm{M} ; \mathrm{p} \leq 0.0001$ : not shown) animals. The $\mathrm{AD}$ genotype had no effect on circulating leptin $\left(A P P^{+/+} \times\right.$ $P S 1^{+/+} 81 \pm 12 \mathrm{ng} / \mathrm{mL}, \mathrm{n}=12 \mathrm{~F} / 26 \mathrm{M}$ vs. $A P P^{\Delta N L / \Delta N L} \times$ $\left.P S 1^{P 264 L / P 264 L} 99 \pm 12 \mathrm{ng} / \mathrm{mL}, \mathrm{n}=15 \mathrm{~F} / 23 \mathrm{M} ; \mathrm{p}=0.3\right)$. The Lepr $^{d b / d b} \times A P P^{\Delta N L / \Delta N L} / P S 1^{p 264 L / P 264 L}$ mice exhibited decreased survival compared with all other genotypes, particularly in the males, which had a 50\% attrition rate by 10 months (Figure 1e-f). Since there is little apparent difference in the tested metabolic parameters between $\mathrm{Lepr}^{+/+}$and $\mathrm{Lepr}^{\mathrm{db} /+}$ mice, we chose to focus on the Lepr ${ }^{+/+}$and Lepr ${ }^{d b / d b}$ genotypes for subsequent experiments. For simplicity, we will refer to the four main genotypes as WT $\left(\mathrm{Lepr}^{+/+} \times A P P^{+/+} / \mathrm{PSI}^{+/+}\right), \mathrm{db}$ $\left(\mathrm{Lepr}^{d b / d b} \times A P P^{+/+} / P S 1^{+/+}\right), \mathrm{AD}\left(\mathrm{Lepr}^{+/+} \times A P P^{\Delta N L / \Delta N L} /\right.$ $\left.P S 1^{P 264 L / P 264 L}\right)$, and db/AD (.Lepr ${ }^{d b / d b} \times A P P^{\Delta N L / \Delta N L} /$ $\left.P S 1^{P 264 L / P 264 L}\right)$. Middle-aged $d b$ and $d b / A D$ mice also had impaired insulin sensitivity (Figure 1g: $F[15,177]=4.64$, $\mathrm{p} \leq 0.0001)$. Collectively, these data indicated that the $d b$ homozygous mice had metabolic dysfunction. Blood pressure was not different in middle-aged diabetic mice compared with nondiabetics, although there was a modest tendency (Figure $1 \mathrm{~h}: \mathrm{p} \leq 0.1$ ) for it to be slightly lower overall.

\section{$\beta$-amyloid}

We have shown previously that leptin downregulates expression of the $\gamma$-secretase components, particularly presenilin [28]. We reasoned that leptin resistance, as seen in obesity and diabetes, would likely increase PS1 expression in the brain and, as a consequence, $\beta$-amyloid deposition in the $d b / A D$ mice. In order to visualize the AD pathology, brains from middle-aged mice were sectioned and stained for $A \beta$ (Ab4G8 - specific for $A \beta_{17-24}$ ). As expected, only mice containing the AD-related mutations in APP and PS1 were positive for A $\beta$-containing plaques (Figure 2a-d). Quantitation of plaque burden indicated that the number of plaques present in $d b / \mathrm{AD}$ mice decreased relative to $\mathrm{AD}$ mice $(0.104 \pm 0.012$ vs. $0.168 \pm 0.013$ A.U.; $\mathrm{p}<0.001 ; \mathrm{n}=9 \mathrm{AD}, 10 \mathrm{db} / \mathrm{AD} ; \mathrm{not}$ 


\section{a}

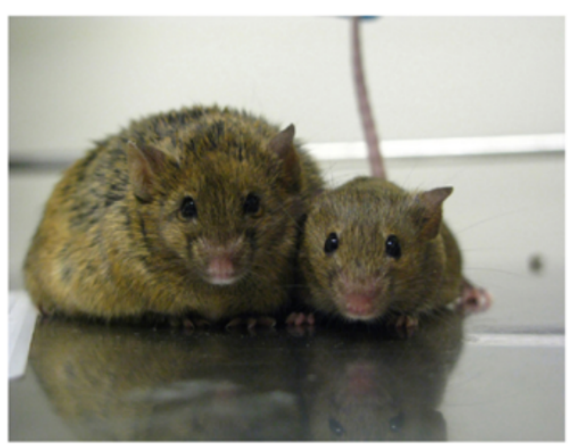

C

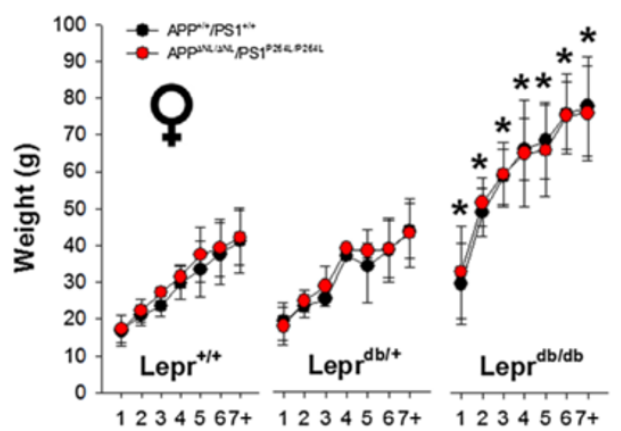

$\mathbf{e}$
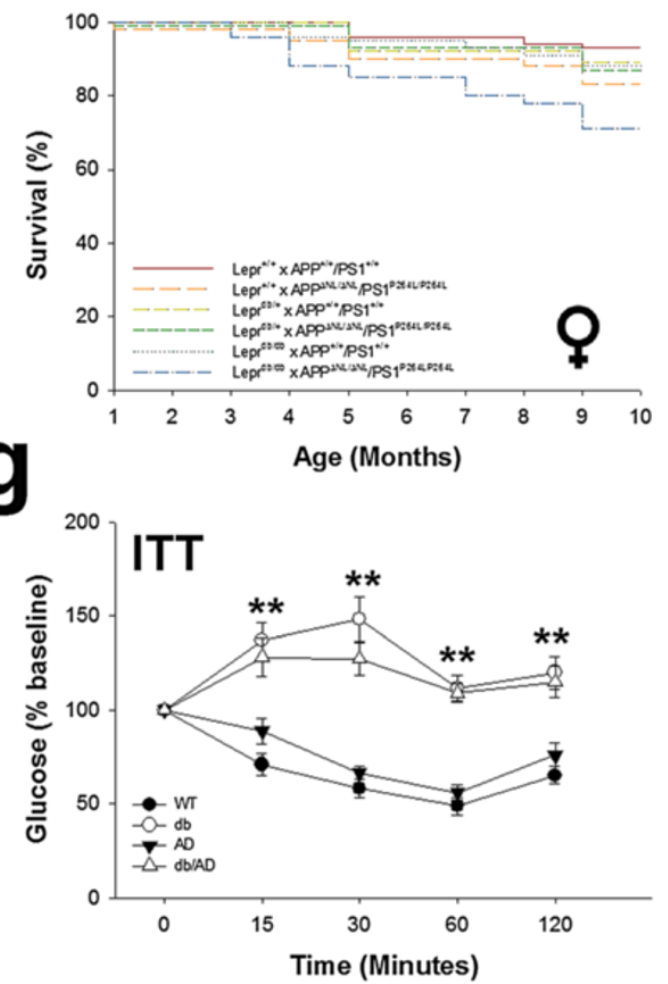

b

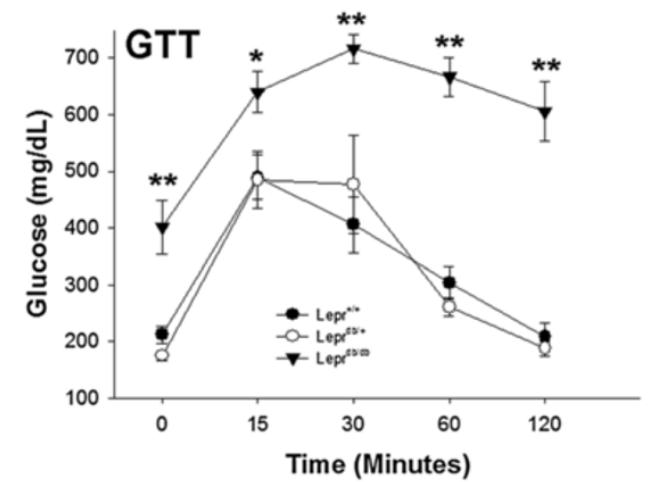

d

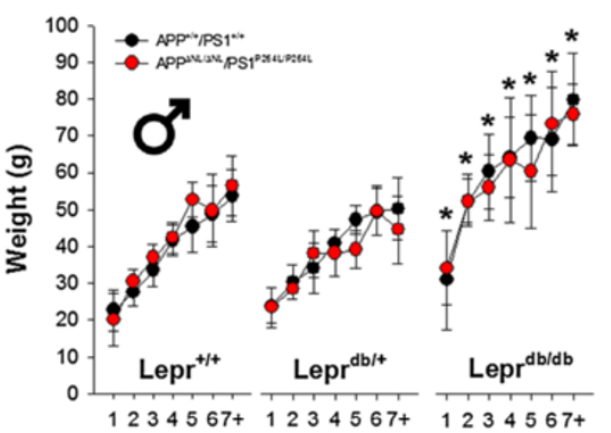

f
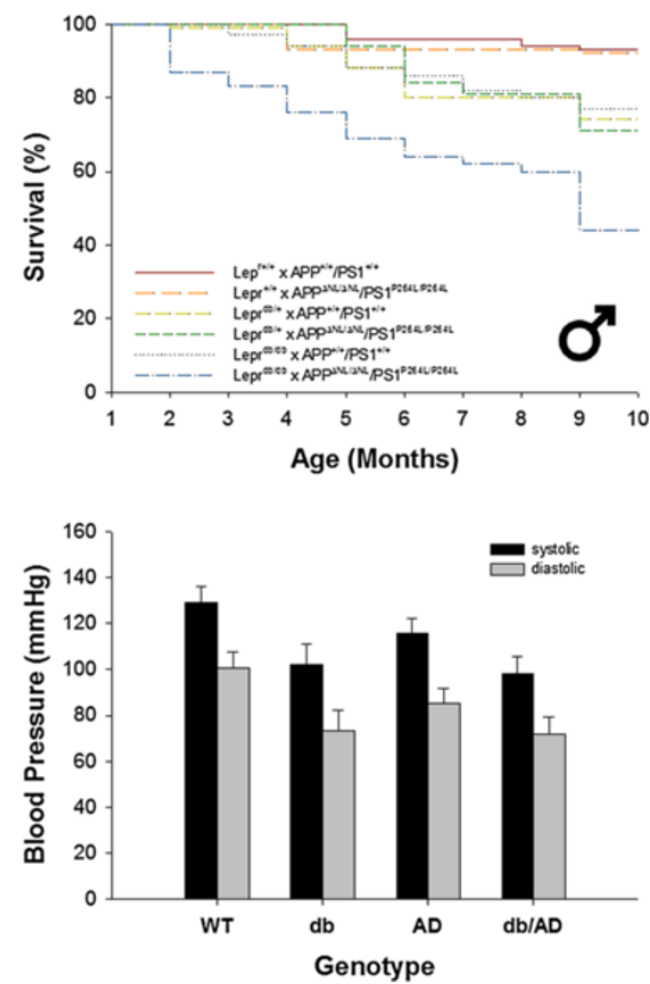

Figure 1 (See legend on next page.) 
(See figure on previous page.)

Figure $1 d b / A D$ characteristics. The diabetic Lepr ${ }^{d b / d b}$ mouse was crossed to the APP/PS1 knock-in model of AD to create the $d b / A D$ line. (a) Mice homozygous for the $d b$ gene were obese (female, 9 months old; left: Lepr ${ }^{d b / d b}$ mouse; right: Lepr ${ }^{d b /+}$ mouse). (b) Lepr ${ }^{d b / d b}$ mice showed an impaired response to glucose $\left(F[2,30]=38.2, p \leq 0.0001\right.$ for the $d b$ genotype overall, $n=13$ Lepr $^{+/+}, n=5$ Lepr $^{d b /+}, n=18$ Lepr $^{d b / d b} ; * *=p \leq$ $0.01,{ }^{*}=p \leq 0.05$, Tukey's LSD). The AD genotype did not affect the GTT (not shown). (c - d) Lepr ${ }^{d b / d b}$ mice showed substantial weight gain from an early age. Weight was relatively stable after $\sim 7$ months, and there was no effect of the AD genotype $\left({ }^{*}=p \leq 0.01\right.$, t-test; Holm-Bonferroni [27] correction; $\mathrm{n}=\sim 14$ mice / genotype). Female (e) and male (f) Lepr $r^{d b / d b} \times A P P^{4 N L} / \mathrm{NLL} / P S P^{p 264 L / P 264 L}$ mice had reduced survivability compared with other genotypes, though the males had a particularly high attrition rate. $\left(\mathrm{N}=367 \mathrm{~F} / 359 \mathrm{M}\right.$ : Lepr ${ }^{\text {db/db }} \times \mathrm{APP}^{\text {ANL/ANL }} / \mathrm{PS}^{\text {P264L/P264L }}, \mathrm{n}=56 \mathrm{~F} / 53 \mathrm{M}$;

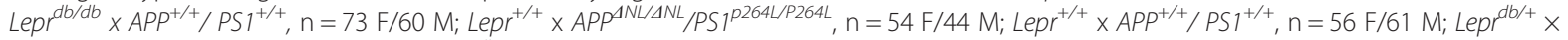

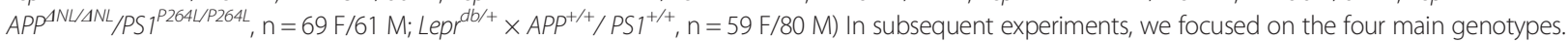
For simplicity we have named them $W T, d b, A D$, and $d b / A D$. (g) Lep ${ }^{d b / d b}(d b$ and $d b / A D)$ mice were insulin resistant $(F[15,177]=4.64, p \leq 0.0001$ for the $d b$ genotype overall; $W T, n=14 ; d b, n=13 ; A D, n=20 ; d b / A D, n=18 ; \sim 6$ months of age; ${ }^{*}=p \leq 0.05,{ }^{* *}=p \leq 0.01 ;$ Dunnett's test, relative to Lepr ${ }^{+/+}$ $(W T$ and $A D))$. (h) Blood pressure was not different, although there was a modest tendency $(F[2,15]=3.24, p \leq 0.1)$ for it to be slightly lower overall in Lepr $^{d b / d b}$ mice regardless of the AD genotype, at least at this age ( $n=5-7$ mice / genotype, $\sim 7-8$ months of age).

shown). Contrary to the effect on plaques, the $\mathrm{db}$ mutation increased expression of PS1 protein (Figure 2e; p $<0.002$ ) Expression of BACE1 $\left(\mathrm{Lepr}^{+/+} 0.89 \pm 0.06 ; \mathrm{Lepr}^{\mathrm{db} /+} 0.87 \pm\right.$ 0.03; Lepr ${ }^{d b / d b} 0.80 \pm 0.05$ A.U.) and BACE2 $\left(\right.$ Lepr $^{+/+} 0.83$ \pm 0.05 : epr $^{d b /+} 0.85 \pm 0.03$;epr $^{d b / d b} 0.84 \pm 0.04$ A.U.), the $\beta$-secretase proteins, was unaffected by the $\mathrm{db}$ genotype ( $\mathrm{n}=8 \mathrm{~F} / 7 \mathrm{M} \mathrm{Lepr}^{+/+} ; 13 \mathrm{~F} / 11 \mathrm{M} \mathrm{Lepr}{ }^{d b / d b} ; 22 \mathrm{~F} / 28 \mathrm{M}$ Lepr $^{d b /+}: \mathrm{p} \geq 0.41$ for both proteins: not shown). The $\mathrm{db}$ mutation significantly increased tau phosphorylation (Figure 2f: $\mathrm{p}<0.003$ ), although no neurofibrillary tangle pathology was observed (not shown). On the other hand, $\mathrm{A} \beta$ oligomers were significantly elevated in diabetic mice (Figure 2g: $\mathrm{p}<0.0005$ ). Young (3 months) $A D$ and $d b / A D$ mice had approximately equal amounts of total $\mathrm{A} \beta$ (Figure 2h: $\mathrm{p}<0.3$ ). At 6 and 12 months, there was still no overall effect of the $d b$ genotype on $A \beta$ levels (Figure $2 \mathrm{i}-\mathrm{j}: \mathrm{p}<0.23$ for $\mathrm{A} \beta_{\text {total }}: \mathrm{p}<0.07$ for $\mathrm{A} \beta_{1-40}$ ) though there was a modest, but significant, reduction in $\mathrm{A} \beta_{1-42}$ (Figure $2 \mathrm{k}: \mathrm{p}<0.01$ ).

Cerebral amyloid angiopathy (CAA), in which $A \beta$ is deposited in the vasculature, is a co-morbidity in many AD patients [29]. We therefore hypothesized that excess $\mathrm{A} \beta$ was created, but was deposited in blood vessels rather than the brain parenchyma in the $d b / A D$ mice. To investigate this possibility, we pursued a variety of histopathological staining techniques. There was no appreciable Congo Red, Thioflavin $\mathrm{S}$, or resorufin staining in any of the aged $d b / A D$ mice tested, nor did we detect any $\mathrm{A} \beta$ immunoreactivity in large or small blood vessels (not shown). Additionally, there was no co-labeling of amyloid (by Amylo-Glo) and anti-collagen IV-labeled vessels (Figure 3a). These data demonstrate a lack of vascular deposition and indicate that CAA is not a primary pathology in these mice. Additionally, we hypothesized that excess $A \beta$ could have been produced, but cleared from the brain at an increased rate in the $d b / A D$ mice. We therefore measured plasma $A \beta$ levels. Neither $\mathrm{A} \beta_{1-40}$ (Figure 3b: $\mathrm{p}<0.18$ ) nor $\mathrm{A} \beta_{1-42}$ (Figure $3 \mathrm{c}: \mathrm{p} \leq$ $0.06)$ were significantly increased in the plasma of older $d b / A D$ mice, compared to $A D$ mice. We also reasoned that increased activity of clearance enzymes could also account for a loss of $A \beta$. However, neither NEP (Figure 3d) nor IDE (Figure 3e) activities were increased by the $d b$ genotype. In fact, the diabetic mice displayed significantly reduced activities of these major clearance enzymes (NEP; IDE; $\mathrm{p} \leq 0.01$ for both), compared to non-diabetic mice. Expression of endothelin-converting enzyme (ECE1) protein was unaffected by the $d b$ genotype (Figure $3 \mathrm{f}$ : $\mathrm{p}<0.65$ ). Similarly, mRNA expression of ECE1 (Figure 3g) and ECE2 (not shown) was unaffected by genotype ( $\mathrm{n}=$ $1 \mathrm{~F} / 4 \mathrm{M} \mathrm{WT} ; 2 \mathrm{~F} / 4 \mathrm{M}$ db; $1 \mathrm{~F} / 3 \mathrm{M} \mathrm{AD} ; 1 \mathrm{~F} / 3 \mathrm{M} d b / A D$ : $\mathrm{p} \geq 0.13$ for both genes).

\section{Cognitive deficit}

Since the diabetes phenotype did not significantly impact amyloid accumulation, we next determined if there was an effect on cognition in these mice. We tested older mice using a standard Morris Water Maze paradigm. While there was no difference in swim distance on the first day of training (Figure 4a: $\mathrm{p}<0.38$ ), the $d b / A D$ mice had significantly longer swim paths on each of the subsequent days ( $\mathrm{p} \leq 0.04$ on each of days $2-5)$, indicating a learning and/or memory impairment. Neither $d b$ nor $A D$ mice showed any significant impairment at this age ( $p \geq 0.13$ for each genotype). Swim speeds were not significantly different on the first training day (WT 374 \pm 18; $A D 356 \pm 21 ; d b 368 \pm 18 ; d b / A D 352 \pm 18 \mathrm{~mm} / \mathrm{s}$ : $\mathrm{p} \geq 0.4$ for all comparisons: not shown) demonstrating that $d b / A D$ mice are capable of swimming as well as other genotypes. After the fifth day of acquisition trials, we performed a probe trial during which the platform was removed. In this trial, $d b / A D$ mice spent significantly less time in the target quadrant (Figure 4b: $\mathrm{p}<$ 0.04 ) and less time in proximity to the platform location $(\mathrm{p}<0.01)$. Since diabetics are prone to retinopathy and blindness, we wanted to exclude a profound visual impairment that would affect performance on the Morris Water Maze. We, therefore, performed a visual acuity test in which the platform location was visible and cued. All animals, with the exception of one $d b / A D$ mouse, 


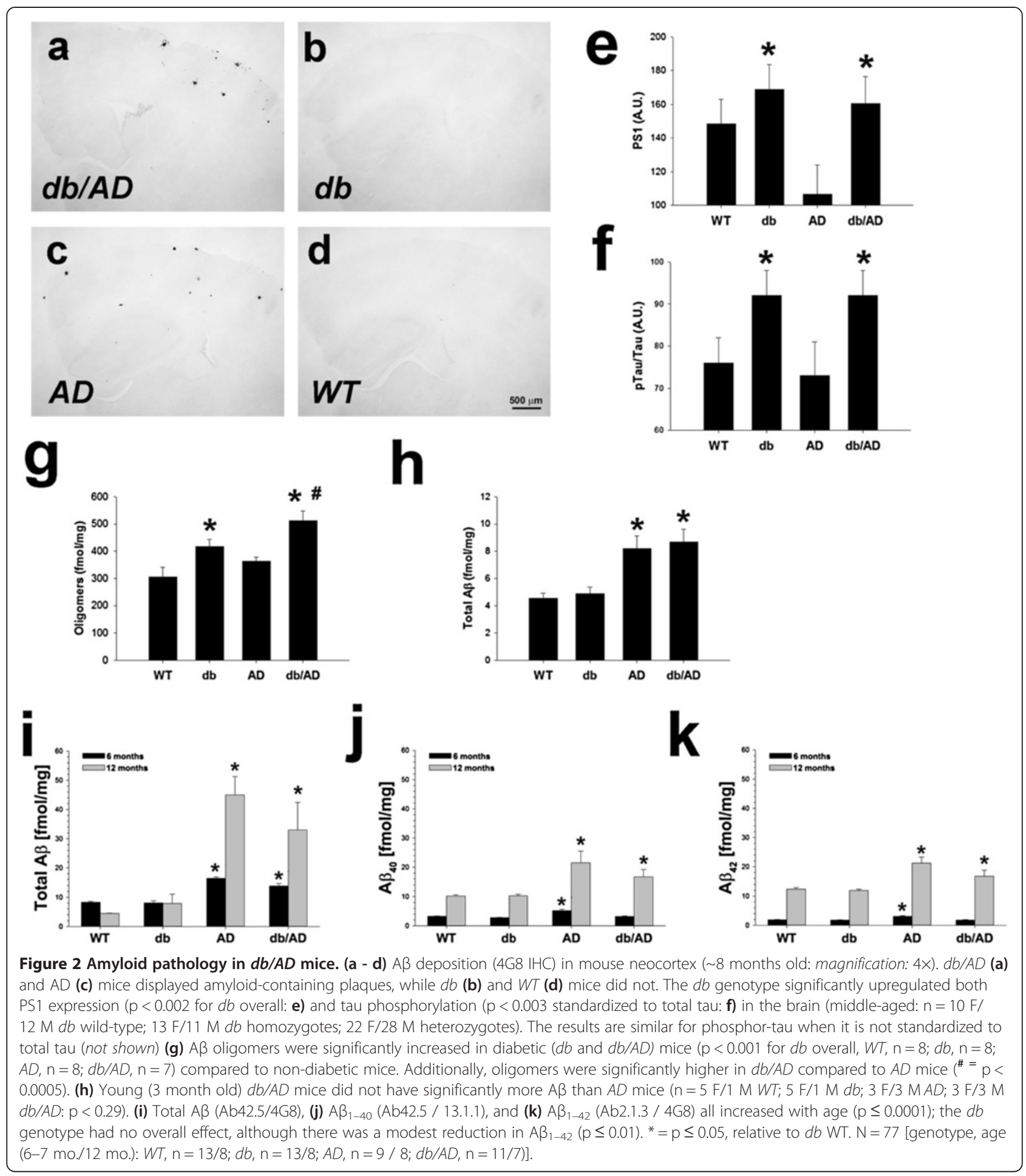

were able to locate the cued platform $\left(x^{2}=3.22\right.$ : $\left.p<0.36\right)$. We also analyzed the visual acuity data using an ANOVA: the $d b$ genotype had no effect on either swim distance (WT 2610 $\pm 2059 ; A D$ 3576 $\pm 2511 ; d b 5805 \pm 1757 ; d b /$ $A D 9700 \pm 3173 \mathrm{~mm}: \mathrm{p}<0.07$ : not shown) or latency to platform (WT 10.6 $\pm 3.4 ; A D 11.7 \pm 3.6$; db $13.45 \pm 2.4 ; d b$ / $A D 21.6 \pm 4.5$ seconds: $\mathrm{p}<0.12$ : not shown), indicating that visual impairment could not account for the deficit. These data indicate that intersection of the both diabetes and $\mathrm{AD}$ is necessary for cognitive impairment. 


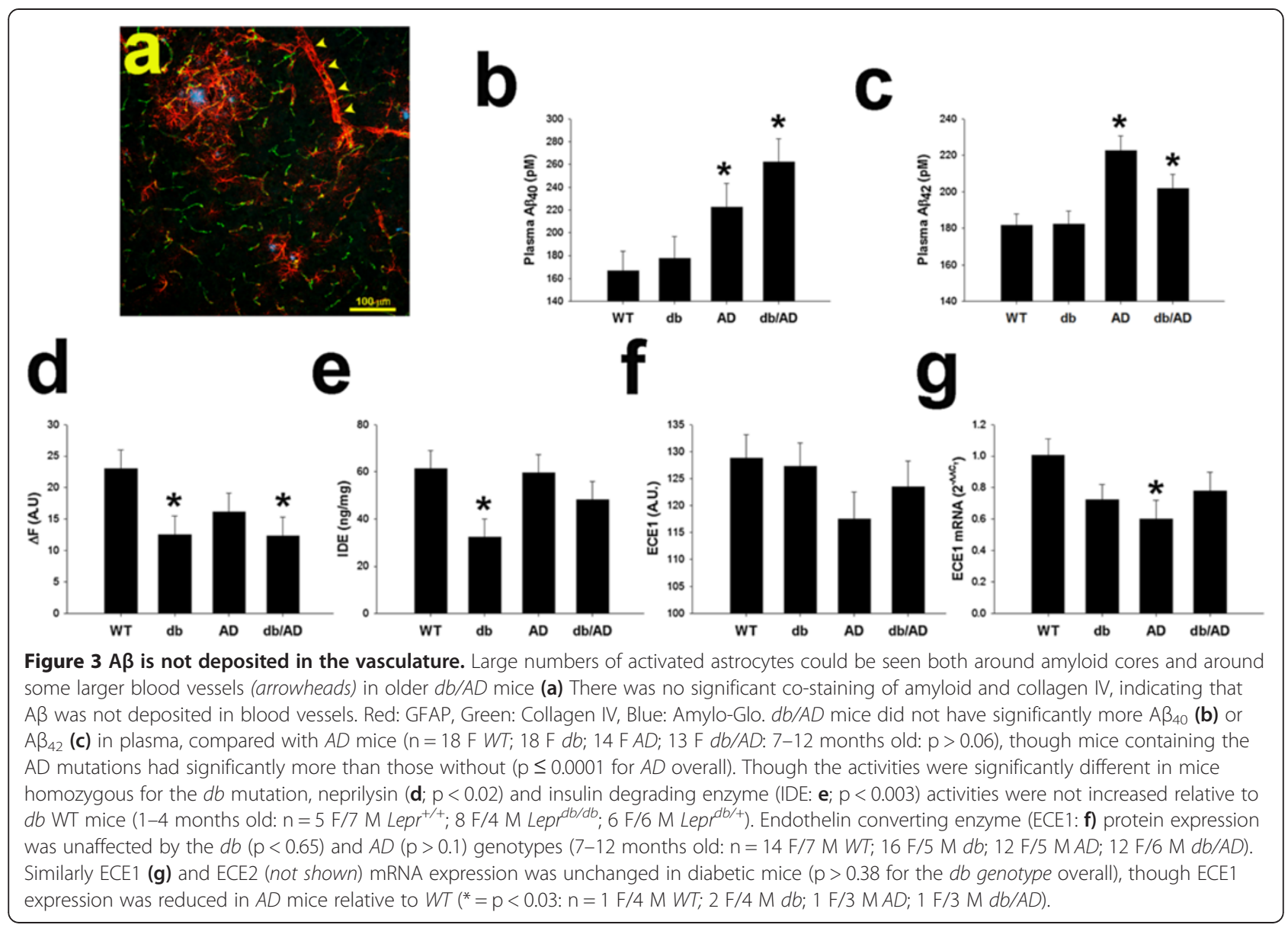

\section{Synapse loss}

Because synaptic dysfunction and subsequent loss have been implicated in AD- associated memory impairment [2-4], we next measured the amount of the synaptic marker PSD95 in older mice. Neither diabetes nor the
$A D$ genotype significantly affected the level of PSD95 in the brain ( $p>0.1$ : Figure 5), indicating that the number of synapses is not substantially reduced in the $d b / A D$ mice at the age at which we have observed learning and/ or memory deficiencies.

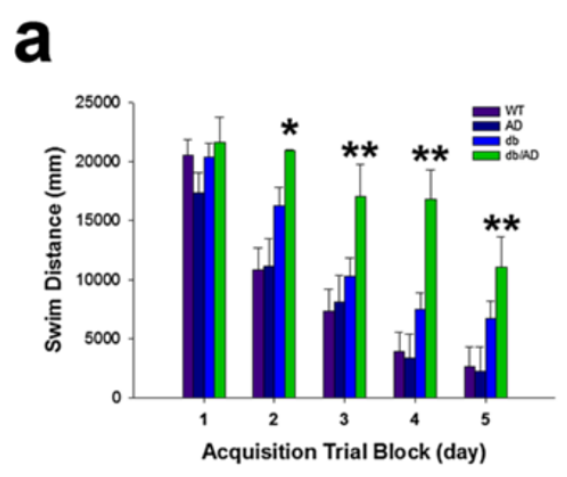

b

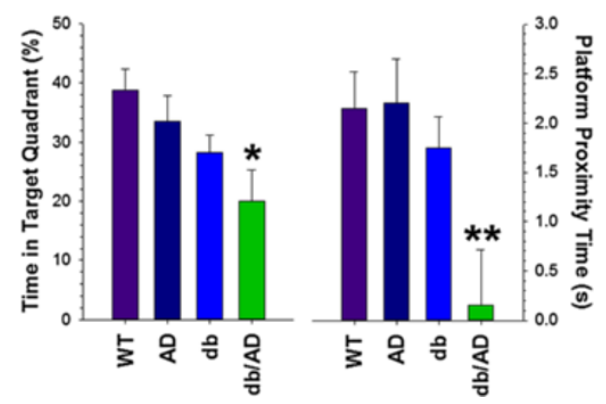

Figure $4 \mathrm{db} / \mathrm{AD}$ mice display impaired cognition. $d b / A D$ mice showed a significant acquisition deficit in the Morris Water Maze (a): ANOVA $p$-value by day: $0.4,02,0.05,0.001,0.03)$ using a standard paradigm of 4 trials/day (mean swim distance is shown for each block: $(W T, n=4 \mathrm{~F} / 4 \mathrm{M}$; $A D, n=4 F / 2 M ; d b, n=6 F / 5 M ; d b / A D, n=7 F / 1 M)$. (b) $d b / A D$ mice did not learn the location of the hidden platform, as shown by probe trial (ANOVA, $p<0.03$ ). The $d b / A D$ mice spent less time in the target quadrant, and less time in proximity to the platform location $\left(^{*}=p \leq 0.05\right.$, ${ }^{* *}=p \leq 0.01$. Tukey's test, relative to WT). All groups performed similarly on the cued version of the task (both distance $(p<0.07)$ and latency $(p<0.12)$, indicating that the $d b$ and $d b / A D$ mice did not have a profound visual impairment (not shown). 


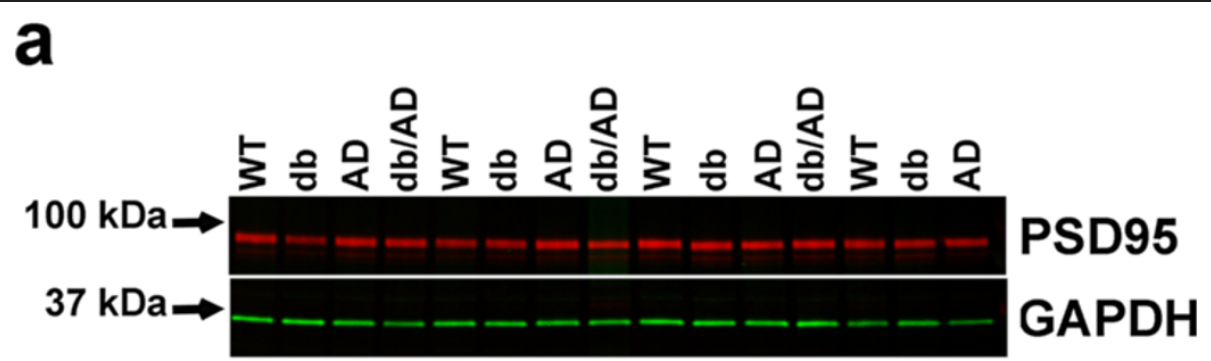

b

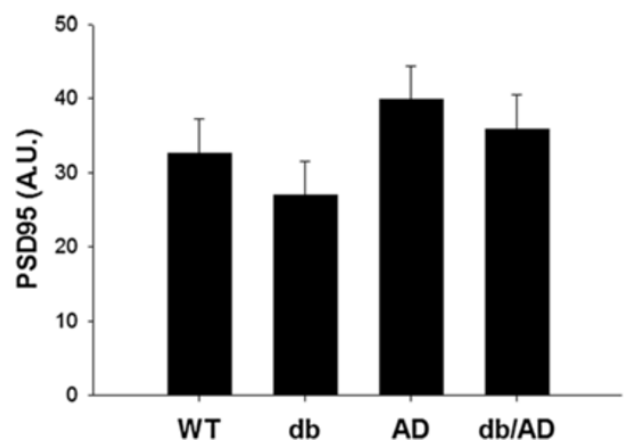

Figure 5 Synapse Loss in $\mathbf{d} b / A D$ mice. (a) A representative immunoblot of PSD95 expression in brains from older $d b / A D$ mice. The immunoblot was visualized with an Odyssey Infrared Imager (LI-COR). Red = PSD95, Green = GAPDH. (b) Analysis of PSD95 expression in the four main genotypes. PSD95 expression was standardized to that of GAPDH in the same lane. PSD95 expression was unaffected by either the $d b$ ( $p>0.3)$ or the $A D(p>0.09)$ genotype.

\section{Cerebrovascular abnormalities}

Since the learning and memory deficit in $d b / A D$ mice was not obviously attributable to accumulation of $A \beta$ or synapse loss, we next focused on changes in the cerebrovasculature. We examined the brain vasculature in older mice using vascular corrosion casting followed by scanning electron microscopy. $W T$ and $d b$ mice had normal appearing vasculature (Figure 6a). By contrast, $A D$ and $d b / A D$ mice displayed a marked pattern of cerebrovascular pathologies. We observed evidence of widespread saccular aneurysms, often occurring at the vessel branch points (Figure 6b). Some of the mice tested also presented with extensive clusters of apparent aneurysms along the arteries and arterioles (Figure 6c) as well as arterial blebbing that may represent weakened areas of the vessel wall (Figure 6d). We next scored the aneurysm pathology on a four-point scale $(0=$ none; $1=1$ possible; $2=1-3$ definite; $3=4+$ definite) and found that aneurysms were significantly more numerous in mice with the $A D$ genotype $(A D$ and $d b / A D$ mice $1.7 \pm 0.23$ vs. $W T$ and $d b$ mice $0.45 \pm 0.24: \mathrm{F}[1,15]=14.14, \mathrm{p}<0.002$ for the $A D$ genotype overall; $\mathrm{N}=4-5 \mathrm{~F} /$ genotype: not shown). The presence of the diabetes genotype did not significantly increase the number of aneurysms $(\mathrm{p}<0.2$ for the $d b$ genotype overall).

Because aneurysms are unstable and prone to rupture, we next looked for evidence of hemorrhage in the $A D$ and $d b / A D$ mice using Prussian blue staining for hemosiderin. Prussian blue staining showed a significant incidence of microhemorrhages in older $d b / A D$ mice $(\mathrm{n}=7$; $\left.X^{2}=4.75, \mathrm{p}<0.03\right)$; we did not find microhemorrhages in genotypes other than the $d b / A D(\mathrm{n}=9$ : Figure $6 \mathrm{e}-\mathrm{f})$, including $A D$ mice, which also displayed significant aneurysm pathology.

We scanned a separate cohort of older mice using small animal magnetic resonance imaging (MRI) in order to visualize areas of hemorrhage and infarcts. Indeed, the majority of the $d b / A D$ mice tested $(11 / 15)$ showed evidence of multiple vascular events by MRI (Figure 7a-b, $\mathrm{h}-\mathrm{j})$. Histological staining of brains from the scanned mice was negative for Prussian blue staining (indicating the lack of hemorrhage). Moreover, micrographs from the same neuroanatomical level as the largest event detected by MRI showed obvious necrosis in the surrounding tissue and an obvious lack of Prussian blue positive staining (Figure 7c-d). The histological data suggest that the vascular events are likely ischemic strokes. By contrast, no WT (0/9: Figure $7 \mathrm{e})$ or $d b(0 / 10$ : Figure $7 \mathrm{f})$ and only a small number of $A D$ (2/9: Figure $7 \mathrm{~g})$ mice presented with strokes, suggesting that the presence of both the $d b$ and $A D$ genotypes is required to promote these events $\left(\mathrm{x}^{2}=\right.$ 21.769; $\mathrm{p} \leq 0.0001)$. In addition, there were multiple events present in the $d b / A D$ mice (Figure $7 \mathrm{~h}-\mathrm{j}$ ), whereas only one or two were present in the $A D$ mice positive for strokes. 


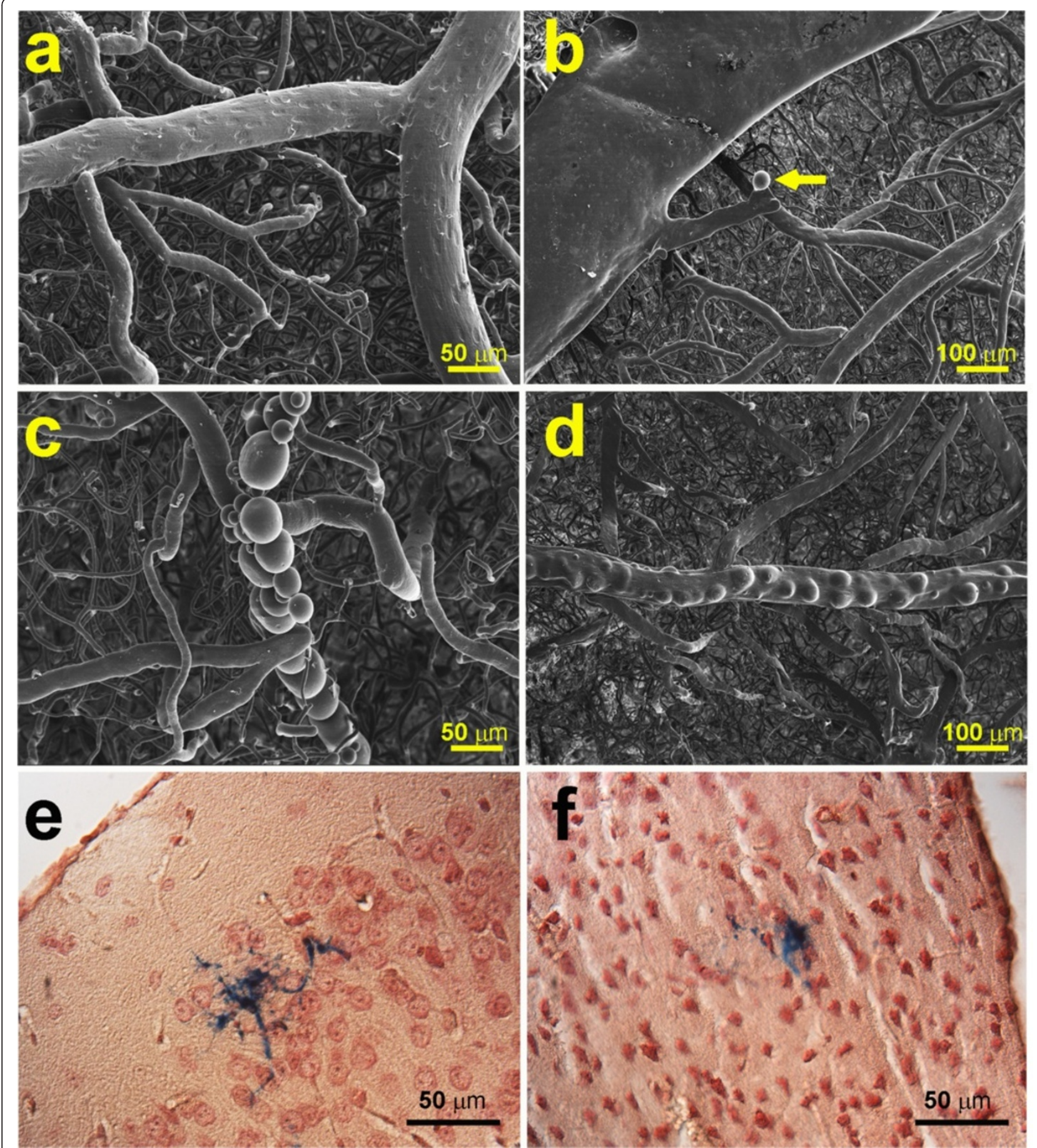

Figure 6 Cerebrovascular pathology in $d b / A D$ mice. SEM images of vascular casts from brains of 4 mice (a-d). (a) Relatively normal appearing cerebrovasculature of a WT mouse (large vessel is a small artery; note the clear endothelial cell nuclear imprints and their elongated shapes).

(b) Aneurysm (arrow) in the brain of an $A D$ mouse near a large vein. Some of the AD mice exhibited more severe cerebrovascular pathology, possibly representing clusters of saccular aneurysms (c) or arterial blebbing (d). In comparison, WT and $d b$ mice had minimal pathology at this age. (e - f) Prussian blue (with neutral red counterstain) staining showing microhemorrhages in two different cortical areas in older $\mathrm{db} / \mathrm{AD}$ mice.

\section{Passive immunization}

Our data suggest that the intersection of the $d b$ and $A D$ genotypes is necessary to induce strokes in these mice.
In light of this data and the absence of diabetes-induced amyloid accumulation, we believe that the stroke pathology is unlikely to be due to $A \beta$ accumulation. In order 




Figure 7 Stroke pathology in $d b / A D$ mice. Sequential (a posterior to b) T2*-MRI coronal images from an older $d b / A D$ mouse showing a neocortical event (arrow) near the corpus callosum; images are separated by $\sim 300 \mu \mathrm{m}$. (c - d) The brain was sectioned transversely to obtain confirmation of stroke extent. Prussian blue staining with neutral red counterstain showed no evidence of hemorrhage, indicating an ischemic stroke event. P - A: posterior / anterior, for orientation (N.B.: section is perpendicular to scanning axis). (e- j) 70\% of $d b / A D$ mice $(n=11 / 15)$ had strokes (arrowheads); these were rare in $A D$ mice $(\mathbf{g}: n=2 / 9)$, and not found at all in $W T(\mathbf{e}: n=9)$ or $d b$ mice $(\mathbf{f}: n=10)$. All mice imaged were 12-14 months old. The db/AD mice (h - j) often have multiple incidents as opposed to the two AD mice, which only displayed one or two small strokes. Representative cases are shown (all scans are at about the same neuroanatomical level). 
to test this hypothesis, we next performed a pilot study in which we immunized older $d b / A D$ mice with an $\mathrm{A} \beta$ antibody (Ab42.5) for two months. Parenchymal A $\beta$ was significantly reduced via immunization compared to agematched, untreated $\mathrm{db} / \mathrm{AD}$ mice $(\sim 17 \%$ decrease; $\mathrm{n}=6$ / group; $\mathrm{p}<0.006$ : not shown). Though $\mathrm{A} \beta$ was significantly reduced in the brain, there was no evidence that the stroke phenotype was rescued. Most of the treated mice imaged by MRI showed evidence of stroke (4/6 treated vs. 11/15 untreated; $\mathrm{p}<0.67$ : not shown).

\section{Vascular density}

$\gamma$-Secretase has been implicated in the regulation of VEGF-dependent angiogenesis [30-32]. Since we observed an upregulation of PS1 expression in the $d b / A D$ mice in the absence of $A \beta$ accumulation, we hypothesized that PS1 might contribute to the observed vascular pathology through the regulation of angiogenesis. We therefore measured the amount of blood vessels present in the brains of older $d b / A D$ mice. Staining for smooth muscle $\alpha$-actin indicated that the brains of $d b / A D$ mice were significantly more vascularized than those of $W T$ mice (1.35 \pm 0.52 vs. $0.31 \pm 0.52: \mathrm{n}=4 /$ genotype: $\mathrm{p}<0.04$ : Figure $8 \mathrm{a}-\mathrm{b})$. SEM images showed a similar increase in the density of the cerebrovasculature in the brains subjected to vascular corrosion casting (Figure 8c-d). Indeed, median vascular density scores of the SEM images from three blinded, independent raters indicated that the $d b$ genotype significantly increased vascular density (Figure 8e: $\mathrm{N}=19$ : $\mathrm{p}<$ 0.02, Mann-Whitney U-test). The $A D$ genotype had a marginal effect, $(\mathrm{p} \leq 0.05)$. Similarly, $d b / A D$ mice had a greater number of endothelial cells than the other genotypes ( $\mathrm{p} \leq 0.05$; Kruskal-Wallis ANOVA), as measured by the endothelial cell nuclear imprints. Endothelial cell density was correlated with vascular density (Figure $8 \mathrm{f}$ : $\mathrm{p}<0.03)$. Direct measurement of cell size $(68 \pm 27$ cells / animal) from the middle cerebral artery indicated that endothelial cells were smaller in diabetic mice $(\mathrm{F}[3,8]=$ $17.9, \mathrm{p}<0.01)$, and size was inversely correlated with density $\left(R^{2}=0.41, \mathrm{p}<0.02\right)$. Collectively, these data indicate that $d b / A D$ mice had an increase in the number of cerebral blood vessels, supportive of increased angiogenesis or arteriogenesis.

\section{Discussion}

\section{The $\mathrm{db} / \mathrm{AD}$ model}

We have created a unique mouse model that encapsulates features of both T2DM and AD- the $d b / A D$ mouse. These mice are morbidly obese and glucose intolerant at a young age (Figure 1a-d), and have a profound cognitive impairment by 12 months (Figure 4). The $d b / A D$ mice display decreased survival (Figure 1e-f), the cause of which is currently unknown. Male $d b / A D$ mice appear to be more susceptible to premature death, though sexual dimorphism has been noted in many AD models [33-35]. While their lifespan is shortened relative to control genotypes, we were able to routinely age the $d b / A D$ mice beyond 12 months, allowing significant $A \beta$ accumulation, plaque formation, stroke pathology, and cognitive impairment.

Contrary to our expectations, the $d b / A D$ mice did not exhibit increased parenchymal $\mathrm{A} \beta$ accumulation compared with the normoglycemic $A D$ mice (Figure $2 \mathrm{~h}-\mathrm{k}$ ), in spite of the observed increase in PS1 expression (Figure 2e). A $\beta$ oligomers were modestly elevated in both $d b$ and $d b / A D$ mice (Figure $2 \mathrm{~g}$ ), though the potential impact of this increase is unknown at this point. It is possible that the detected oligomers are formed from murine $A \beta$ and, thus, are not toxic. The reason for the relative dearth of excess $\mathrm{A} \beta$ in $d b / A D$ mice is unclear, though it does not appear to be due to stimulation of clearance mechanisms. While we cannot rule out clearance by other enzymes, the major enzyme activities that proteolyze $\mathrm{A} \beta$ (neprilysin, IDE, and ECE) were not increased in $d b / A D$ mice (Figure $3 \mathrm{~d}-\mathrm{g}$ ), nor was there an increase in peripheral $A \beta$ in the plasma (Figure $3 \mathrm{~b}-\mathrm{c}$ ). In addition, we found no evidence that $A \beta$ is deposited in the vasculature (Figure 3a), despite using multiple different staining techniques. Based on this data, it is likely that excess $A \beta$ is simply not made in $d b / A D$ mice. In addition, there is no evidence of a significant reduction in the number of synapses in older $d b / A D$ mice (Figure 5). These findings indicate that neither CAA nor synaptic loss causes the cognitive decline observed in our mouse model.

The most striking feature of this mouse model is the severe vascular abnormalities that are present, apparently in the absence of a corresponding increase in $A \beta$ deposition. Older $A D$ and $d b / A D$ mice exhibited profound aneurysm pathology (Figure 6b-d) and $d b / A D$ mice had small strokes (Figure 7). Though we did observe a few areas of hemosiderin-positive staining in those animals with the largest number of vascular events (Figure 6e-f), we did not see substantial numbers of hemorrhages in the $d b / A D$ animals. Indeed, it is possible that the more extensive pathologies observed by SEM are representative of ischemic stroke, but take on this appearance during the vascular corrosion casting process. In addition, the largest event observed by MRI (Figure 7a-b) did not stain positive for hemosiderin (Figure $7 \mathrm{c}-\mathrm{d}$ ) and was likely ischemic in nature. We feel that infarction is the likely cause of these events, but further characterization will be needed. This is broadly consistent with the type of cerebrovascular disease observed in human diabetics [36,37]. Given that the $d b / A D$ mice were the only genotype to exhibit both stroke pathology and cognitive impairment, we believe that it is these strokes that are responsible for the observed cognitive decline. 


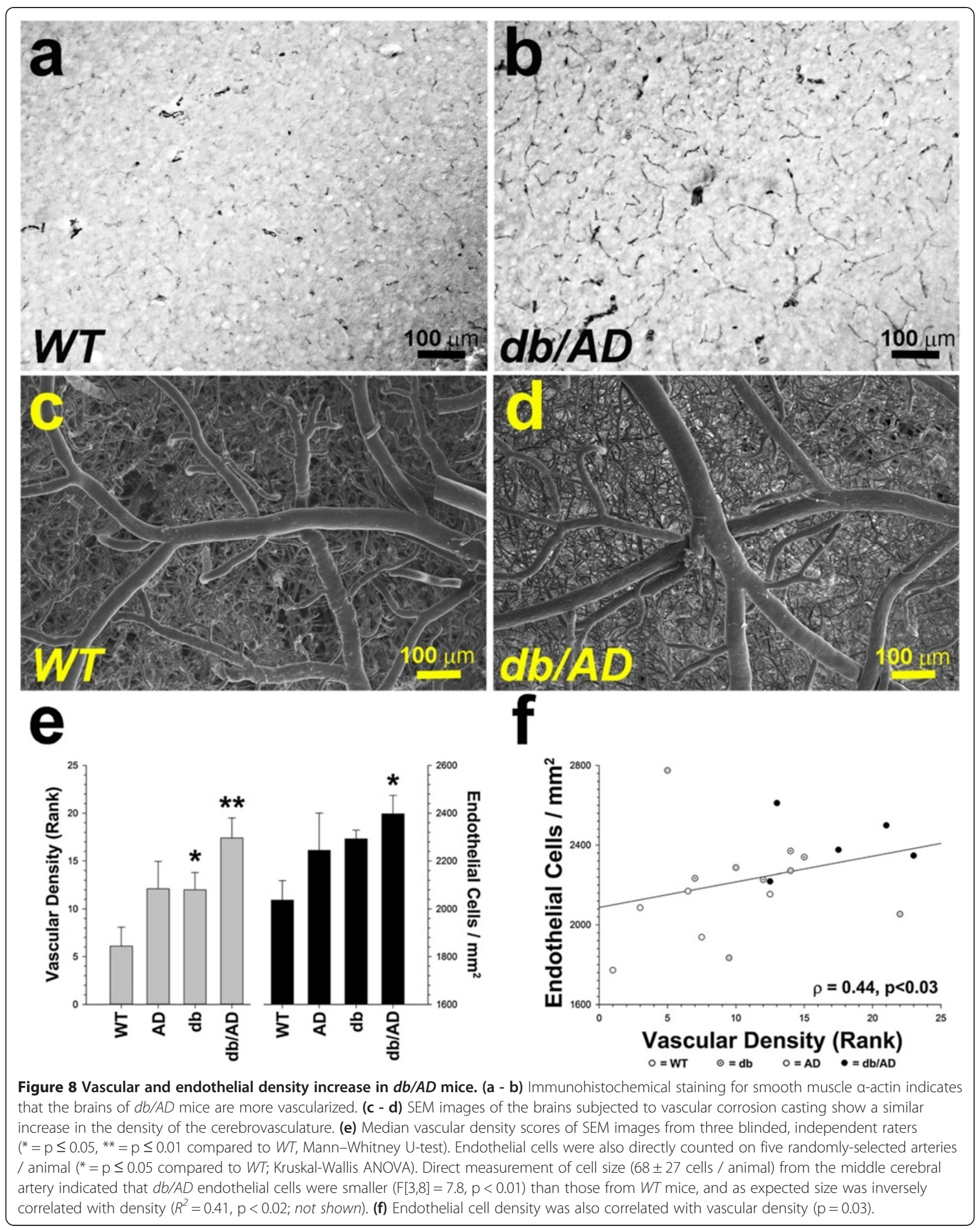




\section{Mechanism of vascular pathology}

Based on our data, it is likely that the aneurysm and stroke pathologies are separable events. Aneurysms were prevalent in $A D$ animals, regardless of diabetic phenotype and were not exacerbated by diabetes. This suggests that the aneurysms may be caused by some feature of the $A D$ genotype. While aneurysms are not typically associated with $\mathrm{AD}$ in humans, increased blood vessel tortuosity, which is associated with aneurysms in other diseases, has been observed [38,39]. In addition, mutations in the presenilin substrate Notch are associated with thoracic aneurysms, likely through crosstalk with TGF $\beta$ signaling $[40,41]$. The mutation in PS1 present in the $A D$ mice may also affect this Notch signaling pathway, resulting in the aneurysm pathology.

On the other hand, the intersection of the $d b$ and $A D$ genotypes was necessary to induce strokes in these mice (Figure 7). In light of this data and the absence of diabetes-induced amyloid accumulation, we believe that the stroke pathology is unlikely to be due to $\mathrm{A} \beta$ accumulation. This hypothesis was supported by preliminary data from our passive immunization study, which showed that stroke incidence was not reduced in $d b / A D$ mice treated with an anti-A $\beta$ antibody, though brain $A \beta$ levels did decrease. While interesting, a more extensive study will be needed for a more definitive conclusion.

Diabetes itself has profound effects on the vasculature. Obesity and diabetes are associated with hypertension and atherosclerosis [42]. In addition, diabetic rodents, including $d b / d b$ mice, have increased neovascularization such as angiogenesis and arteriogenesis [43-45]. This neovascularization consists of immature, unstable blood vessels that display increased permeability of the blood-brain barrier. Similar pathologic angiogenesis occurs in diabetic retinopathy and is thought to involve presenilin and $\gamma$-secretase regulation of VEGF signaling [30,46]. We have evidence that PS1 expression increased in diabetic mice (Figure 2e) regardless of the $\mathrm{AD}$ mutations present- as expected with the use of "knocked-in" genes under endogenous promoters. Consistent with PS1 upregulation, the $d b / A D$ mice have a significantly higher density of blood vessels in the brain than any of the other genotypes tested (Figure 8). Further studies will be needed to determine if neovascularization may indeed play a role in the strokes and/or cognitive impairment, or if some other diabetes-related phenomenon underlies these pathologies. We have shown previously that leptin downregulates PS1 expression in both in vitro and in vivo models [28]. It will be interesting to determine if leptin resistance in the $d b / A D$ mice contributes to neovascularization via regulation of the $\gamma$-secretase complex.

\section{A unique model of mixed dementia}

The form of dementia afflicting diabetic individuals combines elements of vascular pathology, small strokes and AD-related neuropathology. In fact, the amount of $\mathrm{AD}$ pathology is essentially unchanged in cases with a history of T2DM, while cerebrovascular pathology increases $[9,10]$. The $d b / A D$ mice share these features. One way of looking at this seemingly paradoxical observation is that cerebrovascular pathology lowers the threshold for incipient AD pathology to become unmasked as a clinical dementia as has been suggested elsewhere [10].

A small number of studies have examined the linkage between obesity, diabetes and dementia in rodent models $[47,48]$. The majority of these are focused on two paradigms: treatment with streptozotocin (STZ) and feeding a high fat, or typical Western, diet (TWD). STZ, a pancreatic islet toxin, is primarily used to model type I diabetes; thus it does not address the issue of obesity. Although TWD feeding induces obesity, and has some short-term effects on AD-related neuropathology in these models [49-51], these studies have failed to provide any detailed mechanistic insights into how obesity might influence the development of age-related neurologic disease. Further, TWD feeding does not have strong long-term effects on $\mathrm{AD}$ and vascular dementia-related neuropathology [52]. Studies utilizing genetic models of diabetes have been more limited. When $\operatorname{Tg} 2576$ mice, which overexpress $A P P^{\triangle N L}$, are crossed with $\operatorname{Irs} 2^{-/-}$insulin resistant mice, the resulting animals show reduced amyloid pathology [53]. In addition, a recent study examined the outcome of a cross between leptin-resistant $o b / o b$ mice and APP23 mice [54]. These animals showed a very early Morris Water Maze deficit (2-3 months old) unrelated to amyloid load, as the animals had no plaques and no differences in $A \beta$ levels compared with non-diabetic controls. Even at the oldest age examined (12 months old), plaque pathology in these mice was virtually nonexistent, although there was some vascular amyloid in a very small number of animals $(n=3)$. The choice of parental mouse lines has a profound effect on the viability of the resulting mice as well: a cross between the $o b / \mathrm{ob}$ and $T g 2576$ lines yielded animals with significantly reduced viability [55]. While our data are in broadly supportive of these other studies, the $d b / A D$ mice are unique in that they have $A \beta$ plaques, very little vascular-associated $A \beta$, and profound underlying vascular abnormalities, even in the absence of a high-fat diet.

In summary, the $d b / A D$ mouse is a unique model of mixed dementia, possessing both AD-related and vascular pathologies. Older mice present with extensive stroke pathology, arising from a combination of the diabetic and $\mathrm{AD}$ phenotypes, thus leading to significant cognitive impairment. While these data suggest that $A \beta$ is not a primary factor in the observed cognitive impairment, we cannot exclude the possibility that a soluble form of $A \beta$, such as oligomers, may play a role in the cognitive decline. Future studies will focus on the mechanisms 
behind the vascular abnormalities, at both the cellular and tissue levels. Finally, the $d b / A D$ mouse is a novel model in which to test possible therapeutic and preventative strategies to treat cognitive decline from mixed dementia.

\section{Competing interests}

The authors declare that they have no competing interests.

\section{Acknowledgements}

This work was funded by the NIH (NS058382, NS083692, GM103486, DK020579), the Coins for Alzheimer's Research Trust (CART), the American Heart Association (13IRG14330016) and the Alzheimer's Association (IIRG-10-172905). Special thanks to Dr. Shaun Carlson for assistance with confocal pictures Alexandra Sutphin for assistance with histological quantitation, and Dr. Pete Nelson for neuropathological diagnoses. The authors declare no competing financial interests.

\section{Author details}

${ }^{1}$ Sanders Brown Center on Aging, University of Kentucky, 800 S. Limestone, Sanders Brown 211, Lexington, KY 40536-0230, USA. ²Department of Molecular and Cellular Biochemistry, University of Kentucky, Lexington, USA. ${ }^{3}$ Department of Molecular and Biomedical Pharmacology, University of Kentucky, Lexington, USA. ${ }^{4}$ Magnetic Resonance Imaging and Spectroscopy Center, University of Kentucky, Lexington, USA.

Received: 3 June 2014 Accepted: 4 June 2014

Published: 10 June 2014

\section{References}

1. Niedowicz DM, Nelson PT, Murphy MP (2011) Alzheimer's disease: pathological mechanisms and recent insights. Curr Neuropharmacol 9 (4):674-684, doi:10.2174/157015911798376181

2. Ferreira ST, Klein WL (2011) The Abeta oligomer hypothesis for synapse failure and memory loss in Alzheimer's disease. Neurobiol Learn Mem 96 (4):529-543, doi:10.1016/j.nlm.2011.08.003

3. LaFerla FM, Oddo S (2005) Alzheimer's disease: Abeta, tau and synaptic dysfunction. Trends Mol Med 11(4):170-176, doi:10.1016/j. molmed.2005.02.009

4. Selkoe DJ (2002) Alzheimer's disease is a synaptic failure. Science 298 (5594):789-791, doi:10.1126/science.1074069

5. Biessels GJ, Kamal A, Urban IJ, Spruijt BM, Erkelens DW, Gispen WH (1998) Water maze learning and hippocampal synaptic plasticity in streptozotocin-diabetic rats: effects of insulin treatment. Brain Res 800(1):125-135

6. Li XL, Aou S, Oomura Y, Hori N, Fukunaga K, Hori T (2002) Impairment of long-term potentiation and spatial memory in leptin receptor-deficient rodents. Neuroscience 113(3):607-615

7. Messier C (2005) Impact of impaired glucose tolerance and type 2 diabetes on cognitive aging. Neurobiol Aging 26(Suppl 1):26-30, doi:10.1016/j. neurobiolaging.2005.09.014

8. Luchsinger JA, Gustafson DR (2009) Adiposity, type 2 diabetes, and Alzheimer's disease. J Alzheimers Dis 16(4):693-704, doi:10.3233/JAD-2009-1022

9. Ahtiluoto S, Polvikoski T, Peltonen M, Solomon A, Tuomilehto J, Winblad B, Sulkava R, Kivipelto M (2010) Diabetes, Alzheimer disease, and vascular dementia: a population-based neuropathologic study. Neurology 75 (13):1195-1202, doi:10.1212/WNL.0b013e3181f4d7f8

10. Nelson PT, Head E, Schmitt FA, Davis PR, Neltner JH, Jicha GA, Abner EL, Smith CD, Van Eldik LJ, Kryscio RJ, Scheff SW (2011) Alzheimer's disease is not "brain aging": neuropathological, genetic, and epidemiological human studies. Acta Neuropathol 121(5):571-587, doi:10.1007/s00401-011-0826-y

11. Chen $H$, Charlat O, Tartaglia LA, Woolf EA, Weng X, Ellis SJ, Lakey ND, Culpepper J, Moore KJ, Breitbart RE, Duyk GM, Tepper RI, Morgenstern JP (1996) Evidence that the diabetes gene encodes the leptin receptor: identification of a mutation in the leptin receptor gene in $\mathrm{db} / \mathrm{db}$ mice. Cell 84(3):491-495

12. Coleman DL (1978) Obese and diabetes: two mutant genes causing diabetes-obesity syndromes in mice. Diabetologia 14(3):141-148

13. Srinivasan K, Ramarao P (2007) Animal models in type 2 diabetes research: an overview. Indian J Med Res 125(3):451-472
14. Reaume AG, Howland DS, Trusko SP, Savage MJ, Lang DM, Greenberg BD, Siman R, Scott RW (1996) Enhanced amyloidogenic processing of the beta-amyloid precursor protein in gene-targeted mice bearing the Swedish familial Alzheimer's disease mutations and a "humanized" Abeta sequence. J Biol Chem 271(38):23380-23388

15. Siman R, Reaume AG, Savage MJ, Trusko S, Lin YG, Scott RW, Flood DG (2000) Presenilin-1 P264L knock-in mutation: differential effects on abeta production, amyloid deposition, and neuronal vulnerability. J Neurosci 20 (23):8717-8726

16. Anantharaman M, Tangpong J, Keller JN, Murphy MP, Markesbery WR, Kiningham KK, St Clair DK (2006) Beta-amyloid mediated nitration of manganese superoxide dismutase: implication for oxidative stress in a APPNLH/NLH X PS-1P264L/P264L double knock-in mouse model of Alzheimer's disease. Am J Pathol 168(5):1608-1618

17. Murphy MP, Beckett TL, Ding Q, Patel E, Markesbery WR, St Clair DK, LeVine H 3rd, Keller JN (2007) Abeta solubility and deposition during AD progression and in APPXPS-1 knock-in mice. Neurobiol Dis 27(3):301-311, doi:10.1016/..nbd.2007.06.002

18. Niedowicz DM, Beckett TL, Matveev S, Weidner AM, Baig I, Kryscio RJ, Mendiondo MS, LeVine H 3rd, Keller JN, Murphy MP (2012) Pittsburgh compound $\mathrm{B}$ and the postmortem diagnosis of Alzheimer disease. Ann Neurol 72(4):564-570, doi:10.1002/ana.23633

19. Beckett TL, Niedowicz DM, Studzinski CM, Weidner AM, Webb RL, Holler CJ, Ahmed RR, LeVine H 3rd, Murphy MP (2010) Effects of nonsteroidal antiinflammatory drugs on amyloid-beta pathology in mouse skeletal muscle. Neurobiol Dis 39(3):449-456, doi:10.1016/j.nbd.2010.05.018

20. LeVine $\mathrm{H}$ 3rd (2004) Alzheimer's beta-peptide oligomer formation at physiologic concentrations. Anal Biochem 335(1):81-90, doi:10.1016/j.ab.2004.08.014

21. Resende R, Ferreiro E, Pereira C, Oliveira CR (2008) ER stress is involved in Abeta-induced GSK-3beta activation and tau phosphorylation. J Neurosci Res 86(9):2091-2099, doi:10.1002/jnr.21648

22. Vale C, Alonso E, Rubiolo JA, Vieytes MR, LaFerla FM, Gimenez-Llort L, Botana LM (2010) Profile for amyloid-beta and tau expression in primary cortical cultures from 3xTg-AD mice. Cell Mol Neurobiol 30(4):577-590, doi:10.1007/ s10571-009-9482-3

23. Guan H, Liu Y, Daily A, Police S, Kim MH, Oddo S, LaFerla FM, Pauly JR, Murphy MP, Hersh LB (2009) Peripherally expressed neprilysin reduces brain amyloid burden: a novel approach for treating Alzheimer's disease. J Neurosci Res 87(6):1462-1473, doi:10.1002/jnr.21944

24. Latimer CS, Searcy JL, Bridges MT, Brewer LD, Popovic J, Blalock EM, Landfield PW, Thibault O, Porter NM (2011) Reversal of glial and neurovascular markers of unhealthy brain aging by exercise in middle-aged female mice. PLoS ONE 6(10):e26812, doi:10.1371/journal.pone.0026812

25. Wilcock DM, Rojiani A, Rosenthal A, Subbarao S, Freeman MJ, Gordon MN, Morgan D (2004) Passive immunotherapy against Abeta in aged APP-transgenic mice reverses cognitive deficits and depletes parenchymal amyloid deposits in spite of increased vascular amyloid and microhemorrhage. J Neuroinflammation 1(1):24, doi:10.1186/1742-2094-1-24

26. Han BH, Zhou ML, Vellimana AK, Milner E, Kim DH, Greenberg JK, Chu W, Mach RH, Zipfel GJ (2011) Resorufin analogs preferentially bind cerebrovascular amyloid: potential use as imaging ligands for cerebral amyloid angiopathy. Mol Neurodegener 6:86, doi:10.1186/1750-1326-6-86

27. Holm S (1979) A simple sequentially rejective multiple test procedure. Scand J Statist 6:65-70

28. Niedowicz DM, Studzinski CM, Weidner AM, Platt TL, Kingry KN, Beckett TL, Bruce-Keller AJ, Keller JN, Murphy MP (2013) Leptin regulates amyloid beta production via the gamma-secretase complex. Biochim Biophys Acta 1832 (3):439-444, doi:10.1016/j.bbadis.2012.12.009

29. Thal DR, Ghebremedhin E, Orantes M, Wiestler OD (2003) Vascular pathology in Alzheimer disease: correlation of cerebral amyloid angiopathy and arteriosclerosis/lipohyalinosis with cognitive decline. J Neuropathol Exp Neurol 62(12):1287-1301

30. Boulton ME, Cai J, Grant MB (2008) gamma-Secretase: a multifaceted regulator of angiogenesis. J Cell Mol Med 12(3):781-795, doi:10.1111/j.1582-4934.2008.00274.X

31. Cai J, Chen Z, Ruan Q, Han S, Liu L, Qi X, Boye SL, Hauswirth WW, Grant MB, Boulton ME (2011) gamma-Secretase and presenilin mediate cleavage and phosphorylation of vascular endothelial growth factor receptor-1. J Biol Chem 286(49):42514-42523, doi:10.1074/jbc.M111.296590

32. Vartanian A, Gatsina G, Grigorieva I, Solomko E, Dombrovsky V, Baryshnikov A, Stepanova E (2012) The involvement of Notch signaling in melanoma vasculogenic mimicry. Clin Exp Med, doi:10.1007/s10238-012-0190-9 
33. Clinton LK, Billings LM, Green KN, Caccamo A, Ngo J, Oddo S, McGaugh JL, LaFerla FM (2007) Age-dependent sexual dimorphism in cognition and stress response in the 3xTg-AD mice. Neurobiol Dis 28(1):76-82, doi:10.1016/j.nbd.2007.06.013

34. Melnikova T, Savonenko A, Wang Q, Liang X, Hand T, Wu L, Kaufmann WE, Vehmas A, Andreasson KI (2006) Cycloxygenase-2 activity promotes cognitive deficits but not increased amyloid burden in a model of Alzheimer's disease in a sex-dimorphic pattern. Neuroscience 141(3):1149-1162, doi:10.1016/j.neuroscience.2006.05.001

35. Oddo S, Caccamo A, Shepherd JD, Murphy MP, Golde TE, Kayed R, Metherate R, Mattson MP, Akbari Y, LaFerla FM (2003) Triple-transgenic model of Alzheimer's disease with plaques and tangles: intracellular Abeta and synaptic dysfunction. Neuron 39(3):409-421

36. Sweetnam $D$, Holmes A, Tennant KA, Zamani A, Walle $M$, Jones $P$, Wong $C$ Brown CE (2012) Diabetes impairs cortical plasticity and functional recovery following ischemic stroke. J Neurosci 32(15):5132-5143, doi:10.1523/ JNEUROSCI.5075-11.2012

37. Wang CY, Kim HH, Hiroi Y, Sawada N, Salomone S, Benjamin LE, Walsh K, Moskowitz MA, Liao JK (2009) Obesity increases vascular senescence and susceptibility to ischemic injury through chronic activation of Akt and mTOR. Sci Signal 2(62):ra11, doi:10.1126/scisignal.2000143

38. Buee L, Hof PR, Bouras C, Delacourte A, Perl DP, Morrison JH, Fillit HM (1994) Pathological alterations of the cerebral microvasculature in Alzheimer's disease and related dementing disorders. Acta Neuropathol 87(5):469-480

39. de la Torre JC (1997) Hemodynamic consequences of deformed microvessels in the brain in Alzheimer's disease. Ann N Y Acad Sci 826:75-91

40. Loeys BL, Schwarze U, Holm T, Callewaert BL, Thomas GH, Pannu H, De Backer JF, Oswald GL, Symoens S, Manouvrier S, Roberts AE, Faravelli F, Greco MA, Pyeritz RE, Milewicz DM, Coucke PJ, Cameron DE, Braverman AC, Byers PH, De Paepe AM, Dietz HC (2006) Aneurysm syndromes caused by mutations in the TGF-beta receptor. N Engl J Med 355(8):788-798, doi:10.1056/NEJMoa055695

41. Moltzer E, Essers J, van Esch JH, Roos-Hesselink JW, Danser AH (2011) The role of the renin-angiotensin system in thoracic aortic aneurysms: clinical implications. Pharmacol Ther 131(1):50-60, doi:10.1016/j. pharmthera.2011.04.002

42. Ergul A (2011) Endothelin-1 and diabetic complications: focus on the vasculature. Pharmacol Res 63(6):477-482, doi:10.1016/j.phrs.2011.01.012

43. Li W, Prakash R, Kelly-Cobbs Al, Ogbi S, Kozak A, El-Remessy AB, Schreihofer DA, Fagan SC, Ergul A (2010) Adaptive cerebral neovascularization in a model of type 2 diabetes: relevance to focal cerebral ischemia. Diabetes 59 (1):228-235, doi:10.2337/db09-0902

44. Prakash R, Johnson M, Fagan SC, Ergul A (2013) Cerebral neovascularization and remodeling patterns in two different models of type 2 diabetes. PLoS ONE 8(2):e56264, doi:10.1371/journal.pone.0056264

45. Prakash R, Somanath PR, El-Remessy AB, Kelly-Cobbs A, Stern JE, Dore-Duffy P, Johnson M, Fagan SC, Ergul A (2012) Enhanced cerebral but not peripheral angiogenesis in the Goto-Kakizaki model of type 2 diabetes involves VEGF and peroxynitrite signaling. Diabetes 61(6):1533-1542, doi:10.2337/db11-1528

46. Cai J, Wu L, Qi X, Li Calzi S, Caballero S, Shaw L, Ruan Q, Grant MB, Boulton ME (2011) PEDF regulates vascular permeability by a gamma-secretasemediated pathway. PLOS ONE 6(6):e21164, doi:10.1371/journal.pone.0021164

47. Park SA (2011) A common pathogenic mechanism linking type-2 diabetes and Alzheimer's disease: evidence from animal models. J Clin Neurol 7 (1):10-18, doi:10.3988/jcn.2011.7.1.10

48. Thibault $\mathrm{O}$, Anderson $\mathrm{KL}$, DeMoll C, Brewer LD, Landfield PW, Porter NM (2013) Hippocampal calcium dysregulation at the nexus of diabetes and brain aging. Eur J Pharmacol 719(1-3):34-43, doi:10.1016/j. ejphar.2013.07.024

49. Studzinski CM, Li F, Bruce-Keller AJ, Fernandez-Kim OS, Le Z, Weidner AM, Markesbery WR, Paul Murphy M, Keller JN (2008) Effects of short term western diet on cerebral oxidative stress and diabetes related factors in APP x PS-1 knock-in mice. J Neurochem, doi:10.1111/j.1471-4159.2008.05798.x

50. Kohjima M, Sun Y, Chan L (2010) Increased food intake leads to obesity and insulin resistance in the $\operatorname{tg} 2576$ Alzheimer's disease mouse model. Endocrinology 151(4):1532-1540, doi:10.1210/en.2009-1196

51. Julien C, Tremblay C, Phivilay A, Berthiaume L, Emond V, Julien P, Calon F (2010) High-fat diet aggravates amyloid-beta and tau pathologies in the
3xTg-AD mouse model. Neurobiol Aging 31(9):1516-1531, doi:10.1016/j. neurobiolaging.2008.08.022

52. Zhang L, Dasuri K, Fernandez-Kim SO, Bruce-Keller AJ, Freeman LR, Pepping JK, Beckett C, Murphy MP, Keller JN (2013) Prolonged diet induced obesity has minimal effects towards brain pathology in mouse model of cerebral amyloid angiopathy: implications for studying obesity-brain interactions in mice. Biochim Biophys Acta 1832:1456-1462, doi:10.1016/j. bbadis.2013.01.002

53. Killick R, Scales G, Leroy K, Causevic M, Hooper C, Irvine EE, Choudhury Al, Drinkwater L, Kerr F, Al-Qassab H, Stephenson J, Yilmaz Z, Giese KP, Brion JP, Withers DJ, Lovestone S (2009) Deletion of Irs2 reduces amyloid deposition and rescues behavioural deficits in APP transgenic mice. Biochem Biophys Res Commun 386(1):257-262, doi:10.1016/j.bbrc.2009.06.032

54. Takeda S, Sato N, Uchio-Yamada K, Sawada K, Kunieda T, Takeuchi D, Kurinami H, Shinohara M, Rakugi H, Morishita R (2010) Diabetes-accelerated memory dysfunction via cerebrovascular inflammation and Abeta deposition in an Alzheimer mouse model with diabetes. Proc Natl Acad Sci U S A 107(15):7036-7041, doi:10.1073/pnas.1000645107

55. Lubitz I, Haroutunian V, Katsel P, Leroith D, Landa N, Castel D, Shaish A, Shnerb R, Schnaider-Beeri M (2014) Non-viability of crossing the Alzheimer's mouse model Tg2576 with the type 2 diabetes mouse model ob/ob. Neurobiol Aging 35(7):e19-e20

doi:10.1186/2051-5960-2-64

Cite this article as: Niedowicz et al:: Obesity and diabetes cause cognitive dysfunction in the absence of accelerated $\beta$-amyloid deposition in a novel murine model of mixed or vascular dementia. Acta Neuropathologica Communications 2014 2:64.

\section{Submit your next manuscript to BioMed Central and take full advantage of:}

- Convenient online submission

- Thorough peer review

- No space constraints or color figure charges

- Immediate publication on acceptance

- Inclusion in PubMed, CAS, Scopus and Google Scholar

- Research which is freely available for redistribution 